Historic, archived document

Do not assume content reflects current scientific knowledge, policies, or practices. 


\section{UNITED STATES DEPARTMENT OF AGRICULTURE}

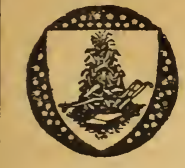

\section{DEPARTMENT BULLETIN №. 1417}

Washington, D. C.

$\nabla$

August, 1926

\section{OZONIUM ROOT ROT}

By

GEORGE L. PELTIER, formerly Plant Pathologist, C. J. KING, Associate Agronomist Office of Colton, Rubber, and Other Tropical Plants, Bureau of Plant Industry, and RAYBURN W. SAMSON, Student Assistant, Department of Plant Pathology

Nebraska Agricultural Experiment Station

\section{CONTENTS}

PART 1.-Studies of Ozonium Root Rot in Arizona and Texas......... 1 Introduction ............. 1 Distribution of Ozonium omnivorum ... 2 Symptoms of the Disease ....... 3 Time of First Appearance ....... 3 Age of Plant Attacked ........ 4 Derelopment of the Disease....... 4 Spread of Root Rot .......... 9 Pure-Culture Isolation of Ozonium omnivorum ............. 11 The Fungus ............ 12 Inoculation Experiments ...... 14 Data Collected in Previous Years.... 15
PART 1.-Studies, etc.-Continued

Observations during the Summer of 1924 . 17

Summary of Part I......... 19 PART II.-The Pathological Anatomy of Ozon. ium Root Rot .......... 20 Introduction ............ 20 Material and Methods of Study .... 20 The Strand Hyphæ ......... 20 Modes of Entrance......... 21 Mechanics of Entrance ........ 21 Development of the Hyphæ in the Tissues 22 Discussion ........... 23 Summary of Part II ........ 24 Literature Cited ........... 27 

UNITED STATES DEPARTMENT OF AGRICULTURE

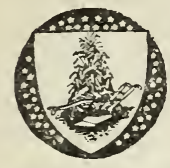

DEPARTMENT BULLETIN No. 1417

Washington, D. C.

$\nabla$

August, 1926

\title{
OZONIUM ROOT ROT
}

By George L. Peltien, formerly Plant Pathologist, ${ }^{1}$ C. J. Kixg, Associate Agronomist, Office of Cotton, Rubber, and Other Tropical Plants, Bureau of Plant Industry, and Rayburx W. SAysox, Student Assistant, Department of Plant Pathology, Nebrasta Agricultural Experiment Station ${ }^{2}$

\section{CONTENTS}

Page

PART I.-Studies of Ozonium root rot in Arizona and Texas...... Introduction of Ozonium omnivorum _. Symptoms of the disease Time of firsteappearance Age of plant ättacked Development of the disease--Spread of root rot. Pure-culture isolation of Ozonium omnivorume_._._.The fungus Inoculation experiments

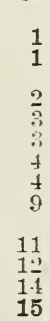

PART I.-Studies, etc.-Continued. Observations during the summer of 1924 Summary of Part I PART II.-The pathological anatom $\bar{y}$ of Ozonium root rot._..... Introduction Iaterial and methods of studyThe strand hrphæ......... Modes of entrance.-Mechanics of entrance Development of the hyphæ in the tissues Summary of Part $\mathrm{II}_{-}$ Page 17 Literature cited.

\section{PART I.-STUDIES OF OZONIUM ROOT ROT IN ARIZONA AND TEXAS}

\author{
By George L. Peltier and C. J. Kisg
}

\section{INTRODUCTION}

Root rot caused by the fungus Ozonium omnivorum Shear is a disease occurring in certain sections of the Southwest. It attacks a great variety of plants, but primarily affects cotton, alfalfa, and fruit and ornamental trees. In spite of the fact that root rot has

1 Plant Pathologist, Nebraska Agricultural Experiment Station; Plant Pathologist, Bureau of Plant Industry, from June 14 to Sept. 13, 1924.

2 The senior writer wishes to acknowledge the assistance of George T. Ratliffe, associate agronomist, Office of Western Irrigation Agriculture, Bureau of Plant Industry, who placed at his disposal all the facilities of the United States San Antonio Field Station. San Antonio, Tex., including all the data and photographs collected since 1916 on Ozenium root rot.

The writers also wish to thank H. F. Loomis, junior agronomist, office of Cotton, Rubber, and Other Tropical Plants, Bureau of Plant Industry, for some of the photographs reproduced in this bulletin. 
been known since 1869 and was first studied in 1888, very little is known regarding its life history or the methods for its control.

A review of the literature on root rot shows that of the many pure-culture inoculations that have been made on susceptible plants under many varied conditions, only a few hare been reported as successful. Attempts to germinate the spores of the conidial stage (Phymatotrichum omnivorum (Shear) Duggar) have not been successful. Likewise, the natural habitat and the life of the fungus in the soil from year to year are rather obscure. Because of its extremely erratic behavior from season to season in the field, all attempts to control it by practical methods under ordinary field conditions have been unsuccessful, so that root rot is still a disease of major importance in the Southwest when judged by the large losses caused by it from year to year. In parts of the irrigated regions cultivated fields hare been turned into pastures, owing to the continued ravages of root rot, and farm lands known to have the disease depreciate in. ralue.

\section{DISTRIBUTION OF OZONIUY OMNIVORUM}

The natural distribution of Ozonium omnivorum in the United States extends from the Red River Valley, which defines the boundaries of Texas, Oklahoma, and Arkansas, south and west through most of Texas and certain irrigated valleys in New Mexico and Arizona, including the Colorado Valley in southeastern California. In Texas the most serious losses from root rot have been reported from the black waxy lands, while in New Mexico. Arizona, and, southeastern California it is chiefly confined to alluvial soils.

So far as known, root rot has nerer been reported in acid soils. All soils of the Southwest are of a calcareous or alkaline nature. It is doubtful whether this disease will ever become prevalent in the cotton-growing States east of the Mississippi River.

That Ozonium omnivorum is indigenous to this region is shown by the fact that land cleared of native regetation and planted to crops susceptible to Ozonium root rot may become badly diseased. A number of instances were observed where cotton planted on land cleared the previous spring was badly diseased during the summer of 1924. Data are also a vailable on the prevalence of root rot on land cleared of native regetation in one of the large and recently developed cotton projects on the edge of the Salt River Talley near Phoenix, Ariz. Here hundreds of acres were cleared of native regetation and planted to cotton. The losses from root rot in certain fields were rather high during the first season. The disease has persisted in these fields in subsequent years, producing a high percentage of root rot whenever planted to susceptible crops.

Further, in a number of instances near San Antonio, Tex., Ozonium strands have been found on the roots of the common mesquite (Prosopis glandulosa Torr.) and granjeno (Momisia pallida (Torr.) Planch.) both in cotton fields cleared the previous season of native regetation and under cotton plants dring from the attacks of root rot. The same trpe of Ozonium strands was found adjacent to these fields on the roots of the abore-mentioned plants growing under natural conditions. During the winter of 1921-25 George T. Ratliffe sent to the senior writer a number of specimens of typical 
Ozonium strands on roots of native plants growing about the station at San Antonio. Therefore, there can be no question that Ozonium is present on the roots of native plants of this southwest region. Many more observations must be made to determine whether or not the fact that the mesquites which cover the entire range where root rot has been reported can be correlated with the presence of Ozonium strands found on their l'oots.

\section{SYMPTOMS OF THE DISEASE}

The first symptom of root rot on cotton is a bronzing or yellowing of the leaves about 24 hours before wilting occurs. This symptom was observed occasionally in Texas. The wilting of the diseased plant is very rapid and can be observed at any hour of the day. It is more pronounced, however, during the hot midday. Sometimes a wilted plant may temporarily recover during a cool night, in wet weather, or during irrigation, but as a rule when once a plant wilts there is no recovery. The wilting of the top occurs first, followed quickly by the wilting of all the leaves from the top to the bottom of the plant. Within 24 hours after wilting the leaves dry up and turn brown but remain attached to the branches. A plant attacked by root rot can be diagnosed from the aboveground symptoms with some assurance by the peculiar manner in which the leaves hang down over the branches and stem and the way they persist on the plant for some time (pl. 1, fig. 1). When a plant, showing the first signs of wilting, is examined, the root system is found to be fairly well rotted at the point of attack. The amount of mycelium found on the wilted plants depends more or less on the percentage of soil moisture and the extent of breaking down of the root tissues. Several days after the plants wilt the bark tissues disintegrate, and the mycelium disappears from the surface of the roots.

The wilting of alfalfa plants attacked by root rot is so sudden that no aboveground symptoms have been observed prior to wilting. The wilting of alfalfa is similar to that described for cotton, except that as the leaves dry on the branches they drop off more readily. Likewise the root system is very badly rotted before wilting occurs. The taproot of alfalfa, being softer and more succulent than the cotton root, favors the more rapid development of the mycelium and consequently the more rapid destruction of the roots.

Large fruit trees may wilt completely in a day, and there appears to be no way of determining by any aboveground symptoms whether or not a tree is attacked by root rot until it is wilted. It happens occasionally, however, that one or more branches on one side of a tree will die, and several months may elapse before the other branches die. In such instances it is usual to find only part of the root system diseased. By the time complete wilting occurs the roots of the trees are badly diseased.

\section{TIME OF FIRST APPEARANCE}

In cotton fields the date of the first appearance of root rot depends on (1) the age of the plants, (2) the prevailing weather conditions, and (3) the number of centers of active mycelium in the soil. An average over a period of years shows that it begins its activity during the first week of June, becoming more serious as the season 
progresses, reaching its maximum sererity during the critical months of July, August, and September. and continuing well into October, depending on weather conditions and on the maturity of the plants. During certain years root rot may appear in May, but it usually makes little headway until the plants are beyond the seedling stage.

In alfalfa fields root rot begins its activity earlier in the season and persists later in the fall than in cotton fields. At Sacaton, Ariz., root rot usually begins its activity in the latter part of April or in May, and may remain active until October. Root-rot activity seems to be closely related with the period of rapid growth of alfalfa.

Small fruit trees begin dying from root rot about the first of June and may continue to die any time during the rest of the growing season. Most of the fruit trees, howerer, die during June and July, both at the station at San Antonio, Tex., and at the United States Field Station at Sacaton, Ariz.

\section{AGE OF PLANT ATTACKED}

Root.rot attacks cotton only rarely at the seedling stage, occasionally before the squares are formed, but most often from the time the first squares are formed until the plants mature. As the season advances, usually increasing percentages of plants are killed until a maximum is reached during July, August, and September. No doubt the plants are more susceptible as they grow older and more active mycelium is present in the soil, but the limiting factor during the critical months appears to be the rainfall or the supply of irrigation water. As a rule, early-planted cotton shows a larger percentage of dead plants at the end of the season than late-planted cotton. This would indicate that the age of the plant is also an important factor.

Alfalfa seeded in the fall does not seem to be subject to root rot until the plants are well established in the late summer or early fall of the following year. Plants 2 years old are apparently attacked with much more vigor. Root rot attacks plants from the abovementioned young stage until the entire field is destroyed or until it is so badly diseased that it is plowed up as of no further value.

In the case of fruit trees, root rot can kill trees of any age. 'The mortality of replanted trees in infested areas is especially high.

\section{DEVELOPMENT OF THE DISEASE}

In order to determine the development of the disease on the underground parts of susceptible plants the following method was employed. A short row of cotton plants showing all stages of root-rot symptoms together with a number of apparently healthy plants was chosen. These plants were then fastened together near the surface of the ground by means of a cord which was tied securely to stakes at each end of the row. A trench about 4 feet deep was dug on each side of the row, care being taken to dig the trench so far a way that none of the lateral roots would be cut off. Then, by means of an ice pick, the soil was dug from around the roots without injuring them severely. The cord above held the plants securely in about the same relative positions. By this method all the larger 
roots were worked out, and detailed observations on the condition of the roots of these plants could be made in the laboratory with the aid of the microscope and dissecting tools. The same method was used in excarating plants in a root-rot spot in an alfalfa field, except that a trench was dug from the centel out through the outer edge of the circle. With fruit trees, a large hole was dug around the collar of the tree, and the lateral roots were uncorered from this point. Many such root excarations were made at the United States field stations at San Antonio, Tex., and Sacaton, Ariz., in cotton and alfalfa fields and on fruit trees.

\section{COTTON}

\section{DETAILED STUDY OF UNDERGROUND PARTS}

From one such excaration of cotton roots on July 19, 1924, at Sacaton, Ariz. (pl. 1), the following detailed notes by groups were made:

Group 1 (four plants): Tops healthy; under the roots of these plants old cotton roots were found from the previous season with strands of Ozonium hrphæ corering their surfaces. While excarating the root systems the hyphæ could be traced from this old root to the collar of the plants. A close examination of the roots showed the presence of a few strand hyphæ with large-celled hyphæ concentrating at certain points. An occasional pseudosclerotium was also observed. Below the points where the wefts were forming, small depressions in the bark were found. No evidences of any lesions were found on the roots of the plants on either side of this group. It therefore must be assumed that the mycelium orerwintered on the old cotton root and that this was the source of infection.

Group 2 (one plant): Top healthy; no lesions on roots; a few strand hyphæ found at collar.

Group 3 (four plants) : Tops showing signs of wilting; taproots sound below 25 centimeters; ${ }^{3}$ all laterals rotted for 5 to 20 centimeters from point of attachment to taproot, but the ends of all were sound. Strand hyphæ. pseudosclerotia, and large-celled hyphæ were plentiful at the collar of these plants; bark sloughed off around collar for about 18 centimeters.

Group 4 (three plants) : Plants have been dead for several days; leares dried and hanging to branches; roots all rotted except at extreme ends of laterals; rery little mycelium present on the dead roots.

Group 5 (three plants): Tops just showing first symptoms of wilt; taproots rotted for 30 centimeters; laterals rotted for 5 to 10 centimeters from point of attachment; both taproots and lateral roots sound below for distances mentioned; presence of mycelial types as described for group 3.

Group 6 (two plants): Plants dead for at least two days; taproots rotted for 35 centimeters; laterals rotted except at ends; point of infection at collar, where bark is sloughed off; presence of mycelium as in group 3, but less pronounced.

Group 7 (four plants) : Plants wilting; taproot rotted for 25 centimeters and laterals for about 15 centimeters; other root portions sound; point of infection at collar, where bark can be sloughed off; mycelial weft heavy around collar of plants.

Group \& (two plants) : Tops healthy; all roots healthy except for one small lesion ( 1 millimeter in diameter) on taproot of one plant; a few strand hyphæ obserred on collar of plants.

Group 9 (four plants): Tops healthy; slight infection found at collar, early stage; only about 10 centimeters of the collar seemed to be involved; lateral roots perfectly sound; one or two lesions extending through bark to stele; mycelium of various types rery plentiful.

Group 10 (two plants): Plants healthy; no mycelium visible with aid of lens on any of the roots. 


\section{SUMMARY OF UNDERGROUND STUNIES}

The detailed notes from a number of root excavations of cotton plants can be summarized as follows: The strand hyphæ are first observed on the taproots. At certain intervals they branch to form a small ball of hyphæ. Directly below these accumulations of strands a small depression in the bark is found, and in this depression a weft of large-celled hyphæ is present. Many such depressions are found on one root. After the depressions have penetrated the bark they apparently do not increase in diameter. When the bark is peeled off, the woody tissues present a dark-brown spot just beneath the depression. During the period in which the depressions are increasing in diameter and depth the mycelium becomes more plentiful both in and around the depressions and on the root.

The next stage in the disease seems to be a penetration of the cambium and the stele by the mycelium, which appears to progress up and down the main taproot and out into the laterals. In most instances the mycelium is found very abundantly on the bark in advance of the rot.

To judge from the rate at which the plants die in a cotton row, the time from the formation of these depressions to the actual entrance of the fungus is a matter of not more than one or two days. Meanwhile the collar of the plant is inclosed in a fungous mass composed of strand hyphæ and mycelium. The wilting of the plants after this stage is reached is a question of only a day or so.

During this stage (wilting), while the strand hyphæ are still very much in evidence, the number of large-celled hyphæ increases rapidly to form a weft. The amount of this type of mycelium formed depends on the percentage of soil moisture and the extent of the breaking down of the root tissues. High soil moisture favors the development of pseudosclerotia in the crevices of the bark or at the lenticels.

Rotting is much more rapid from the point of entrance down into the taproot and out into the laterals than upward. Usually there is a marked constriction between the healthy and diseased tissues at the collar. The healthy tissue is also very sharply delimited from the diseased portion. The fact that the fungus has been observed only in the first foot of soil when not in contact with the roots seems to preclude the possibility of an attack below this level.

Two types of infection were repeatedly observed, depending on the point of attack. In the first type the strand hyphæ first accumulate at a point on the root just below the constriction between the root and the stem, and the depressions are formed in this zone. Wilted plants attacked at this point have healthy laterals except at the point of attachment with the taproot. Plants infected in this manner always show a pronounced constriction of the taproot just below the collar. This point of infection is the one usually found on cotton plants in root-rot spots.

The point of attack for the second type of infection usually is where the main side roots originate. Here infection occurs through depressions located where the small rootlets formed in the cotton seedling stage die off after the permanent side roots are formed. These small rootlets are not connected to the stele, as is the case 
of the larger lateral roots. so that these dead rootlets serve as an entrance for the fungus to the bark tissues. These depressions can be formed at any point in the region where the main sicle roots originate. After entrance is effected the taproot and lateral roots rot very rapidly. During periods of cloudy days and high soil moisture, adventitious roots which may sustain the diseased plant for some time form abore the diseased portion. No pronounced constriction of the taproot occurs. This type of infection is not common, owing probably to the greater depth in the soil at which it occurs. Duggar $(1)^{4}$ has reported tro types of infection and has designated them as centrifugal and centripetal. However, only the centrifugal type of infection was observed by the writers.

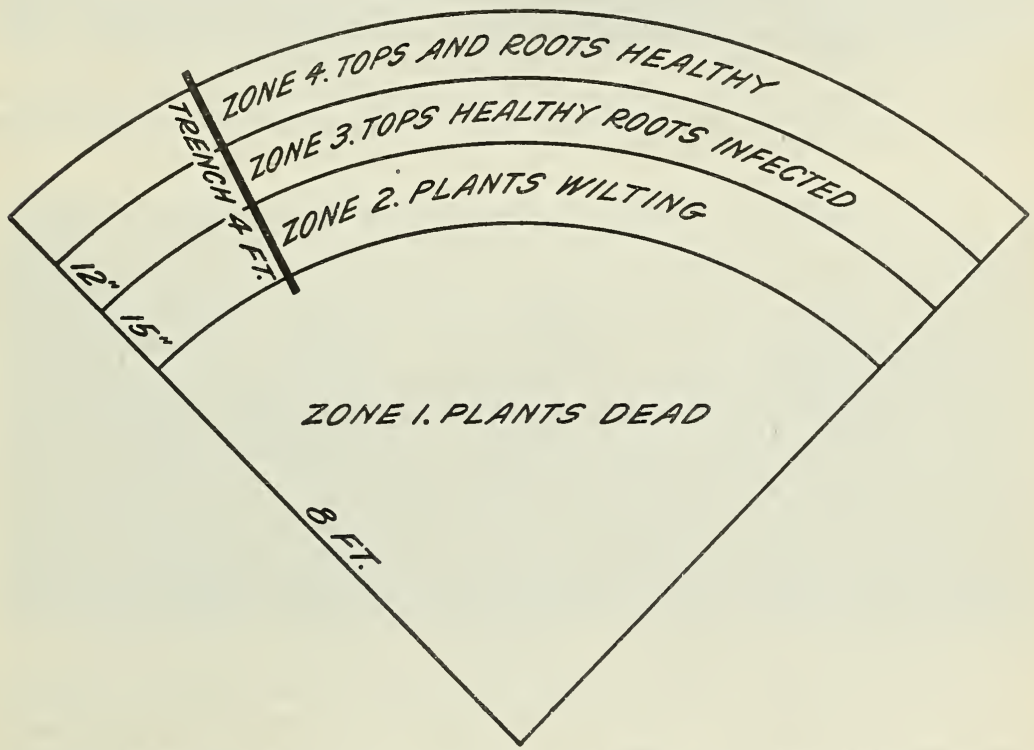

Fig. 1.-A sector of a root-rot spot in aifalfa, showing the different zones folmed by the various stages of the disease from aboveground and underground observations. Sacaton, Ariz.

ALFALFA

DETAILED EXAMINATION OF UXDERGROUND CONDITIONS

Detailed notes on the condition of alfalfa roots excavated from a sector of a spot of root rot in an alfalfa field, made on September 3, 1924, at Sacaton, Ariz., are here presented (fig. 1 and pl. 2):

Zone 1: Plants dead. This zone consisted of weeds. a few weak live plants, and dead plants killed by root rot. The taproots rotted to about 75 centimeters. Sloughing of the bark occurred for 60 centimeters. No mycelium was present on the roots below 50 centimeters. The entire roots above this point were badly disintegrated. Mycelium was rather difficult to find. Below 75 centimeters the taproots were sound and fibrous roots were present. The roots of the plants on the outer edge of this zone were not so badly disintegrated.

Zone 2: Plants wilting. The foliage was wilted and drying up and the leaves were shedding rapidly. Taproots were rotted for about 60 centimeters. Below this point they appeared progressively more healthy and were

"Serial numbers in italic in parentheses refer to "Literature cited" at the end of this bulletin. 
apparently healthy to the 115 -centimeter level. Down to 35 centimeters the bark was more or less disorganized, including some of the wood elements. The mycelial weft extencled from the crown to about 20 to 25 centimeters down the roots, then strand hyphæ of rarying numbers and colors extended to about 45 centimeters farther down the surface of the roots. Below this point for about 10 centimeters there were numerous depressions at points where the fibrous roots entered the taproot. The roots on the outer edge of this zone were not as badly rotted as the others.

Zone 3: Tops healthy; roots infected. The plants nearest zone 2 would wilt soon, while those of the outer edge of zone 3 would not have wilted for two or three days. This was the advance zone, where the strand hyphæ spread out and caused infection. In this zone also the soil was permeated with strand hyphæ. (See pl. 5 fig. 1.) Strand hyphæ were numerous on the taproots for about 25 centimeters. The mycelial weft was just beginning to organize on the upper 15 to 20 centimeters of the root, and many depressions were found around the point where the fibrous roots entered the taproot. The lesions were still small and only in a few cases had they penetrated through the bark. On the last plant in this zone only one or two strand hrphæ were found. No depressions had developed as yet.

Zone 4: Tops and roots healthy. No mycelium of any sort was found on the roots. At the rate the plants died in the wilting zone the strand hyphæ must travel several "centimeters or more a day through the soil.

SUMMARY OF COXDITIONS OBSERTED IN EXCAYATIONS

The notes made from an examination of a number of excarated plants can be summarized as follows: On the underground parts the first eridence of Ozonium is the presence of a few strand hyphæ on a healthy root. The mycelial accumulations generally occur at the base of the small rootlets on the taproot at any point in the first foot of soil. The formation of the depression and the invasion of the cambium and stele are similar to those described for cotton. The amount of mycelium present on the alfalfa roots is more plentiful than on cotton. Rotting of the roots proceeds faster down the taproot than up. The line of demarcation between healthy and diseased tissue at the crown is not nearly so sharply delimited as in the case of cotton nor is there any constriction between these tissues.

Tnder favorable conditions the time interval between the presence of the strand hyphr on healthy roots and the wilting of the plant is approximately a week. Of all the diseased alfalfa and cotton roots examined, no instances were observed in which rotting proceeded from the ends of a side root to the taproot, and no observations were made that showed that the fungus progressed from one plant to another by the contact of a diseased root with a healthy one. Therefore, it appears evident that the fungus progresses through the upper foot of soil irrespective of the root contacts, and only those plants are attacked at the collar which are in the line of the advancing mycelium in the upper foot of soil.

\section{FRUIT TREES}

Owing to the manner in which fruit trees are set and grown in an orchard, the point of infection and the progress of the disease can not be determined as easily as in the case of alfalfa or cotton. The time required by Ozonium to kill a fruit tree depends principally on the size of the tree. To judge from the fruit and ornamental trees that were examined, the principal point of attack seems to be at the crown and on the surface roots, although centripetal infection may 


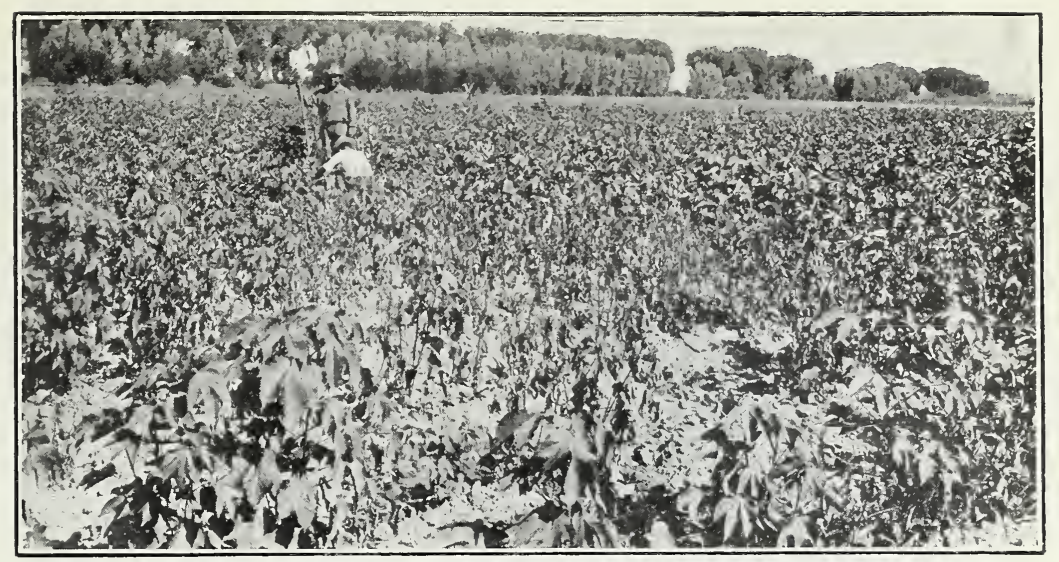

Fig. I.-General View of the Borders in SEction B-2

$A$ trench is being dug in the background for the purpose of examining the root systems of plants infected or dying with root rot

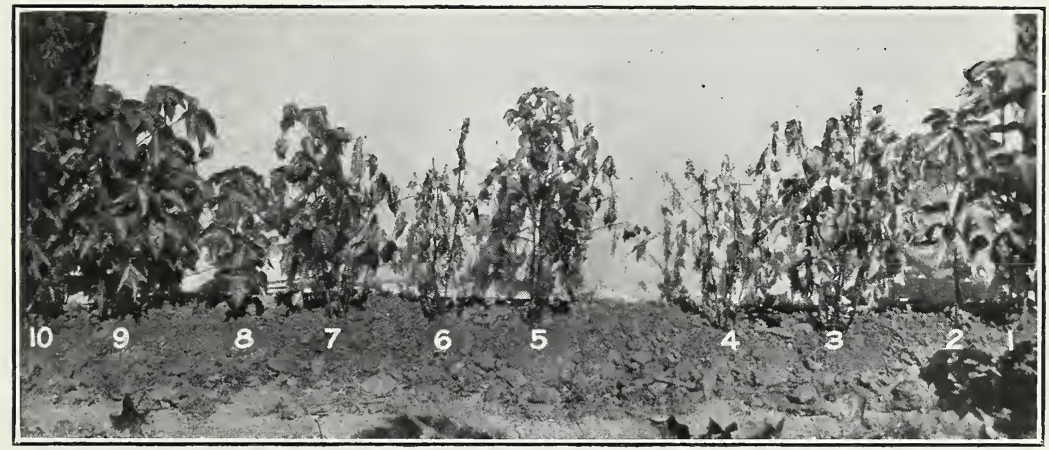

Fig. 2.- Cotton Plants in a Single Row of a Border in Section B-2, SHOWING ALL STAGES OF WILTING

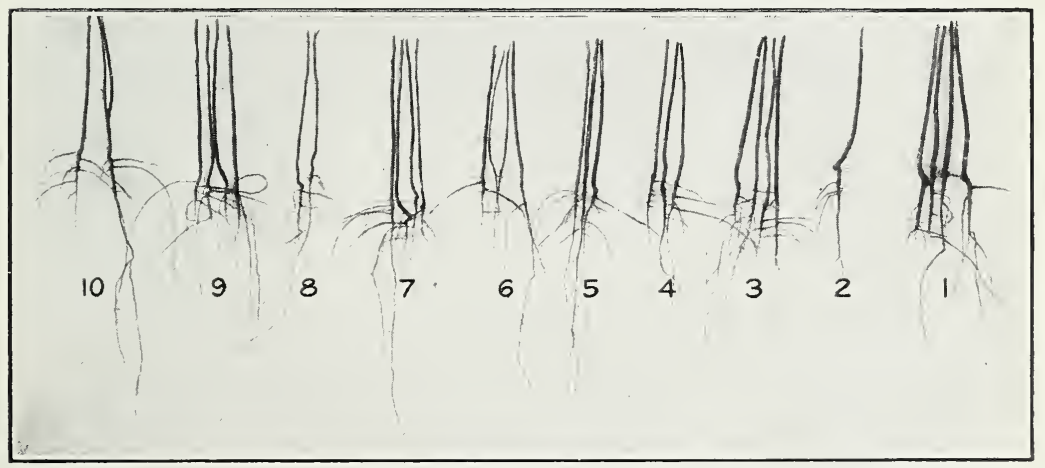

FIG. 3.-UNDERGROUND PARTS OF THE COTTON PLANTS SHOWN IN FIGURE 2 RESULTS OF ROOT-ROT WILTING OF COTTON PLANTS AT THE UNITED STATES FIELD STATION SACATON ARIZ.

Photographed by H. F. Loomis 


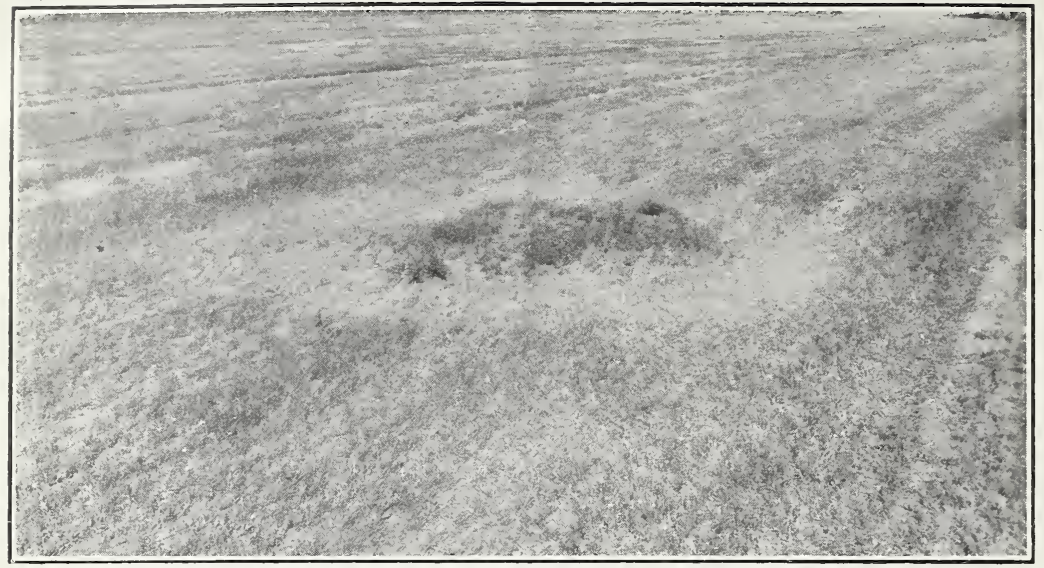

FIG. I.-A TyPicAl SPOT OF ROOT ROT IN AN ALFALFA FIELD

The dead zone with weeds growing in the center is shown just after cutting. The trenches described in the text were made in a spot almost identical with this one. Photographed by H. F. Loomis at the United States Field Station, Sacaton, Ariz.

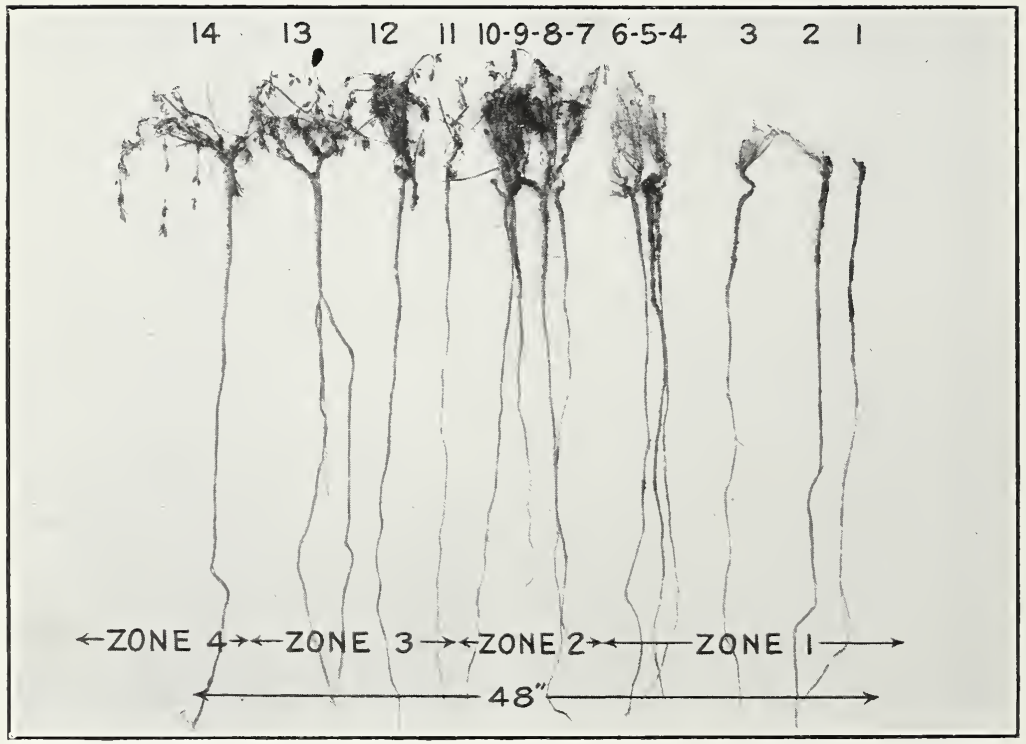

Fig. 2.-Excavated Alfalfa Plants

The various root and foliage symptoms in the different zones of the root-rot spot are shown. Photographed by H. F. Loomis 


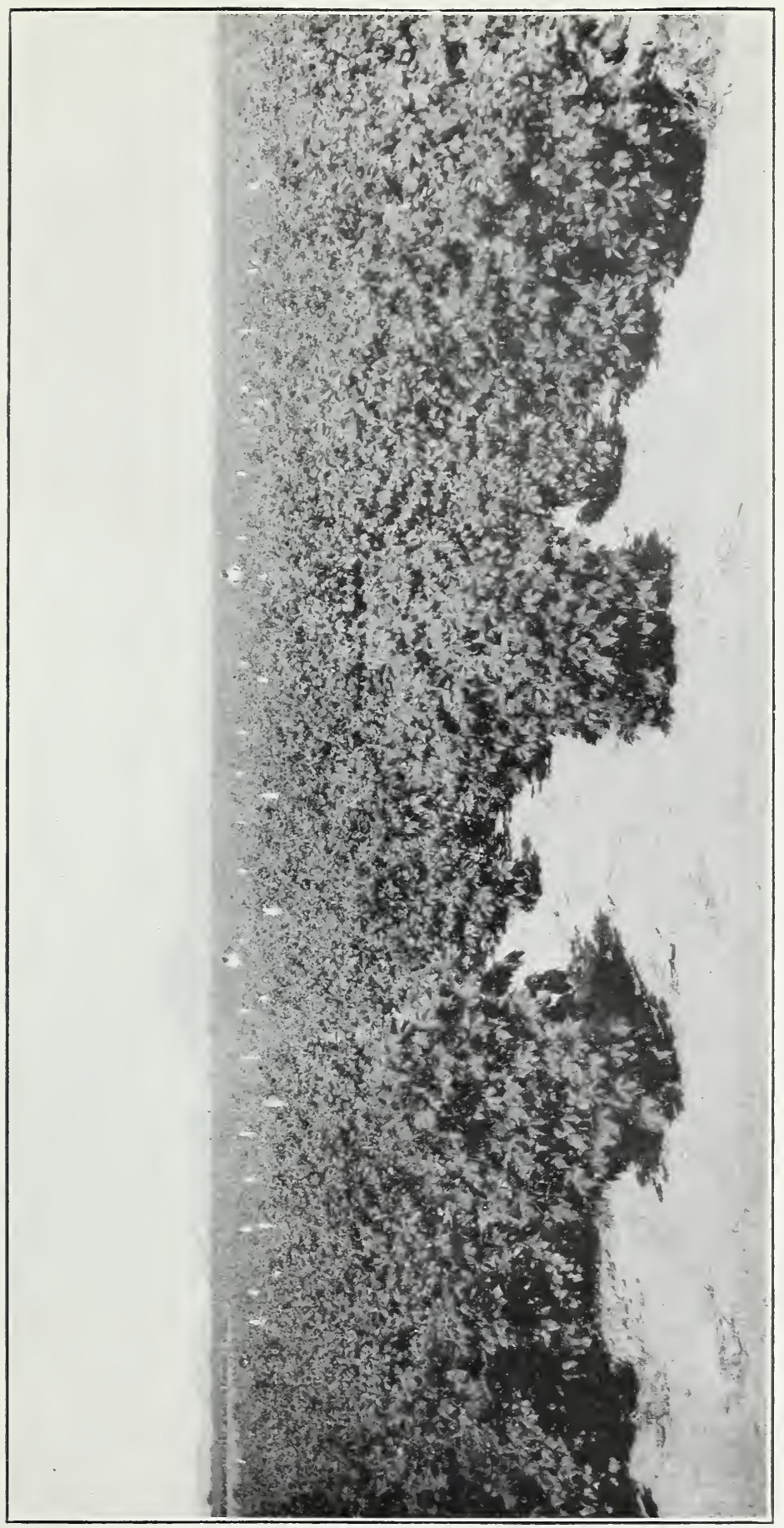




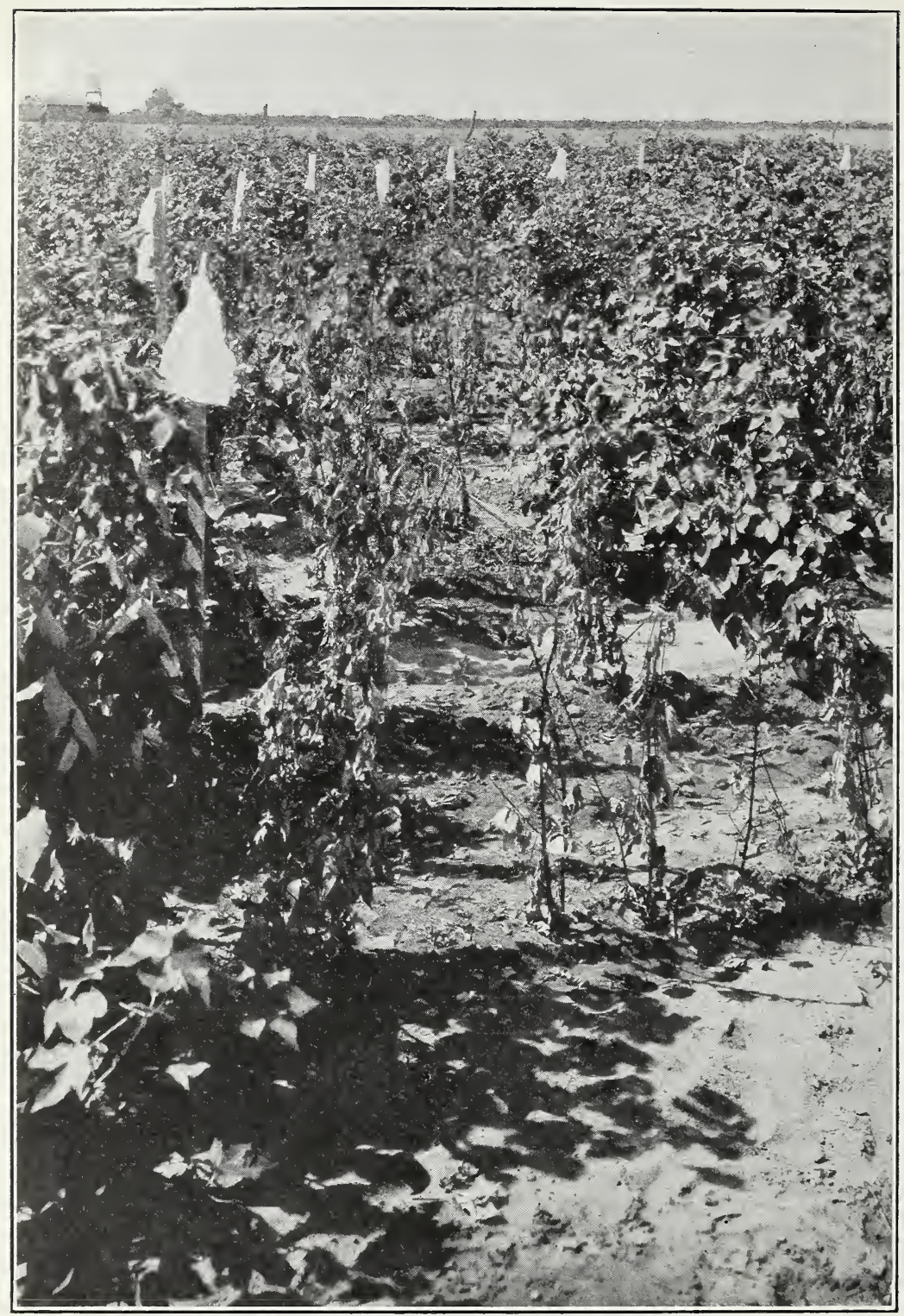

DETAILED VIEW OF PART OF THE CIRCUMFERENCE OF THE SPOT OF ROOT ROT SHOWN IN PLATE 3

Note that the cotton plants in the center of the spot are healthy. The diseased plants are at the periphery of the spot. This illustration shows th 3 spr al of the fungus outward through the soil and also that the active mycelium persists only at the outer edge of a spot from season to season. Photographed by H. F. Loomis 


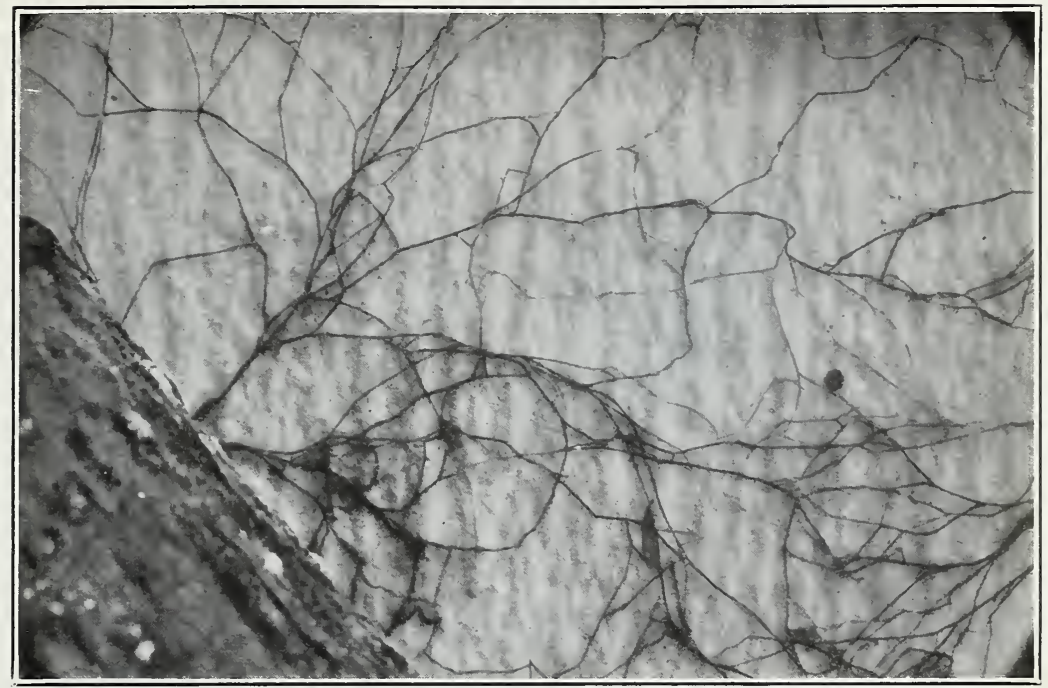

\section{Fig. I.-PORTION OF AN Old INFECTEd COTTON ROOT IN A MOIST CHAMBER}

Note the white mycelium on the roots and the brown strand hyphæ growing upon the surface of the filter paper. Photographed by R. D. Martin (X 3)

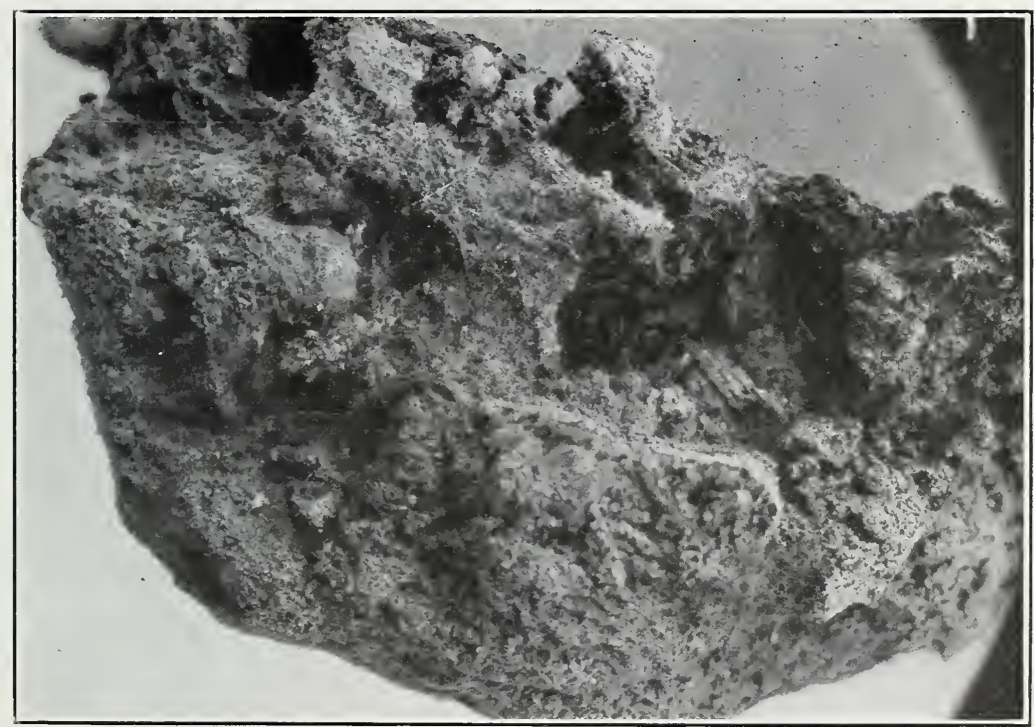

Fig. 2.-SMALL Clump of SOIL TAKEN FROM A DEPTH OF ABOUT 4 INCHES IN A ZONE OF ACTIVE STRAND HYPHIE IN ADVANCE OF THE WILTING COTTON PLANTS

Photographed br H. F. Loomis $(\times 3)$ 
Plate 6
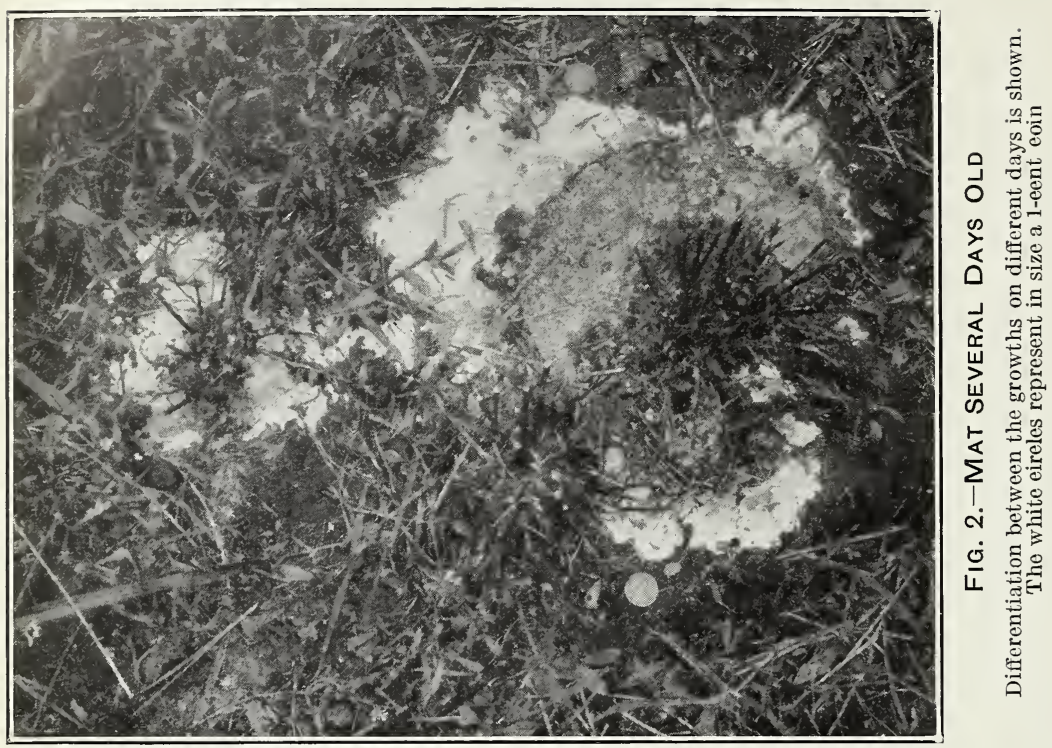

西

ด ब

牙市

造造

¿ี.

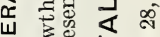

山ل

क

$\Sigma$ छ.ढ

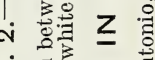

ธ่ ฐี尺 $\Sigma$

馬

这

$\geq$

$\sum_{0}^{Z}$

0 륨

$\sum_{2}$

To

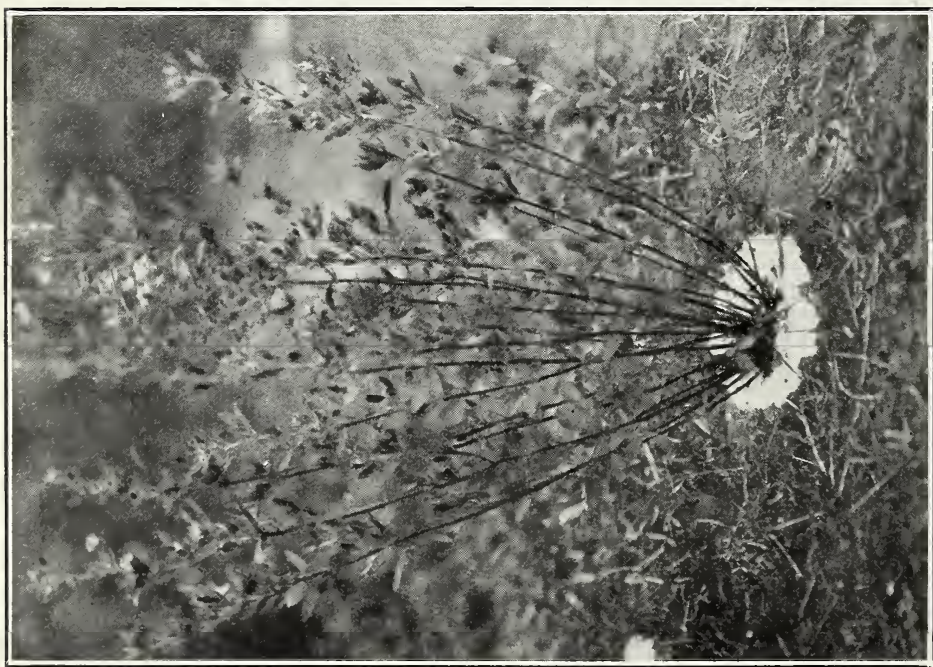

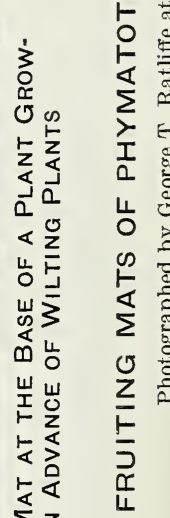


occur. At the crown of most of the trees examined the strands were profuse on the bark and on the surface roots arising from this point. As no fruit trees were examined prior to wilting, the point and manner of entrance of the fungus could not be determined. However. it was noted that the outer ends of all the surface roots were healthy and that the rot on these roots progresses out from the collar.

\section{SPREAD OF ROOT ROT}

Taubenhaus and Killough (8) frequently make the assertion that " root rot spreads underground from contact of infected roots of one plant with adjoining healthy ones of another." All the observations made by the writers show that the spread of the fungus from plant to plant in the field occurs through the soil, irrespective of the root contacts of the susceptible plants, although it may spread more rapidly in one crop than another. Our observations show that the point of attack is nearly always on the taproot within the first foot of soil, whereas the lateral or side roots are usually diseased only at the point of attachment with the taproot. The rotting of the root system is much more rapid down into the roots than upward. As a rule most root parasites tend to advance from the ends of the roots, so that root rot differs in this respect.

If the spread of Ozonium occurred through the contact of a diseased root with a healthy one, then we should expect to find that the rot began at the ends of the laterals and worked up to the main taproot. If such were the case, wilting would be less rapid and more nearly like the wilts caused by Fusarium spp.

Taubenhaus and Killough (8) also state that if Ozonium does not spread "by underground contact of the roots . . . we should find hundreds of plants dying all at once in a given spot." They fail to consider that the active mycelial. zone is always present in advance of the wilting plants, while the mycelium in the zone of wilted plants serves as a food reserve for the advancing strand hyphæ. Thus, through the agency of the advance mycelial strands, the spread of Ozonium takes place directly through the first foot of soil from plant to plant and not by contact of diseased and healthy roots, as maintained by Taubenhaus and Killough (8).

Although the tendency of the fungus is to spread in a circular fashion, the shape of root-rot spots depends to a large degree on the quantity and extent of the underground parts of the susceptible crops in a field.

Generally, the root-rot spots in an alfalfa field assume an almost circular shape, especially under irrigation. In cotton fields the spots are of an irregular shape, although occasionally they may be circular. Two such spots were observed near Sacaton, Ariz., during the summer of 1924. One of them is shown in Plates 3 and 4 .

Although a number of factors are probably involved in the formation of these circles, the most important factor is the quantity of underground parts of the host plant present. In a cotton field, Ozonium may spread faster down a row than across it, because of the fact that this is a line of less resistance and the soil is not disturbed by frequent cultivations.

92792-26-2 
The rapidity with which Ozonium can spread from a given center of infection depends on a number of known and unknown factors. Under irrigated conditions in Arizona, root rot advances in an alfalfa field at the average rate of 1 to 2 meters a month over a period of about seven months. In cotton fields the rate of spread under both dry-land and irrigated conditions is very erratic, and no exact measurements can be given. Under optimum conditions root rot may. spread down a row or rows of cotton plants much faster than in an alfalfa field.

The fact that Ozonium is indigenous and appears in some fields and not in other's when they are first cleared of native vegetation has already been pointed out and can be further illustrated by the following example: The United States Tuma Field Station at Bard, Calif., is and has been free from root rot since its establishment, in spite of the fact that root rot is present and causes serere losses on other farms in the vicinity; in fact, root rot is prevalent on a farm just across the road from the station. If Ozonium can be spread readily by any aboreground agencies, including the spores of the conidial stage, why has root rot not appeared at the Bard station during the past 15 years?

No instances are known where root rot has appeared in a field after it has produced healthy crops of a susceptible plant for a number of years, even though root rot may be present in neighboring fields. Likewise, few instances are known where root rot once well established in a field has ever disappeared, even after a long rotation with nonsusceptible crops. In other words, if root rot does not appear in a field planted to a susceptible crop within one or two years after it is cleared of native vegetation, it is indicated that Ozonium is not present in the soil and that no losses from the disease will result, whereas if root rot does appear, no practicable methods of tillage or rotation are known which can be relied upon to control it. It has been shown, however, that small isolated areas may be freed from root rot by thorough disinfection with a suitable fungicide.

In many ways the spread of Ozonium through the soil is similar to that of many Basidiomycetes which produce fairy rings. It is a well-known fact that the production of the conidial stage takes place just ahead of the wilting zone of plants in cotton and alfalfa spots. While the wilting of the plants occurs in this zone, the advance mycelium is well out in front of the zone (38 to 75 centimeters), attacking the root systems of the plants which still appear healthy above ground. It is suggested that the front line of advancing mycelium uses the reserve food material of the mycelium found on the dying plants, and after the reserve food is used up this mycelium disintegrates. King (4) showed that Ozonium is not active in the dead zone of an alfalfa spot by planting such an area to cowpeas, a very susceptible crop, which remained healthy.

By examining Plates 3 and 4 it will be noted that most of the cotton plants in the interior of the wilting zone which surrounds the root-rot circle are healthy. This root-rot spot is clearly indicative of the way the fungus mycelium moves outward from a given center. The aboveground appearance here shown is rather unusual in cotton, but common in alfalfa fields.

Thus, during the growing season, as root rot spreads, the old mycelium in the dead zone of plants disintegrates, while the active 
mycelium is berond the wilted circle of plants. Likewise, when the growing season is orer the only points where the active mycelium of Ozonium is likely to be present are on the periphery of the dead areas. Ozonium mycelium in the form of strand hyphæ may, per-haps, live through the winter on lire cotton and alfalfa roots, as on native plants already described. and when conditions are again favorable new centers of infection begin at these points where this type of mycelium has withstood the winter. It is not absolutely essential that the roots remain alive, for many observations have been made of dead cotton roots covered with Ozonium mycelium which were not only the source of conidial mats but also producing centers of infection.

Scofield (5) and Taubenhaus and Killough (8) show by diagrams that root-rot spots in cotton fields frequently do not occur in the same place from season to season. but reappear close by in other spots. Perhaps this can be explained by the following analogy: The spread of Ozonium can be compared to the advance of a grass fire. To begin with, a lighted match thrown into the grass may or may not start a fire. If conditions are farorable it may spread rapidly. When conditions are unfarorable it may do little damage and die down. So with root rot; a number of centers of infection in June may spread rery rapidly if all conditions are right. On the other hand, they may make moderate progress or very little, depending on the conditions faroring or inhibiting their spread. During some years Ozonium does much more damage than in others, only a small percentage of plants dying one year and nearly 100 per cent the next. It is especially noticeable in plat experiments that a high death rate over the plat one year is often followed by a much lower death rate the next season. Further, when practically all the plants are killed in a plat one season, the plants begin dying the following year at the outer borders of the plat. A difference between the spread of a grass fire and root rot is that the fire goes out erentually, whereas root rot is able to begin its activities each season and start its destruction from the points where it left off the previous season. Thus, in cotton fields new centers of infection at the periphery of the old spots formed the preceding year tend to advance in all directions, killing all the plants in the line of advance but less completely invading the spot formed the previous year.

These observations may explain why cotton root rot may not recur in the same spots. King (4) has shown that in alfalfa fields the new centers start about 70 centimeters from the periphery of the old spot, and subsequently these new centers merge and advance outward, the extent of regression depending on the number of reestablished plants that are present in the old spot for the fungus to attack.

\section{PURE-CULTURE ISOLATION OF OZONIUM OMNIVORUM}

A summary of the pure-culture isolations of Ozonium omnivorum showed that it could be cultured only from the small fresh lesions (depressions) on the roots. Only rarely were cultures obtained from the taproots, where the mycelial weft and strands were present in any quantity. No cultures were obtained from plants which 
were severely wilted, except occasionally when a young lesion was found farther down on the taproots.

The most successful method used in isolating Ozonium was as follows: Plants just showing the first signs of wilting or healthy appearing plants next to these in a row were dug up and the loose dirt washed off. Bits of tissue with the young lesions present were cut out and dipped in mercuric chloride, 1 to 1,000, for 30 to 60 seconds. Instead of washing off the mercuric chloride as is the custom, the excess of mercuric-chloride solution was taken up with filter paper and the pieces dropped on cotton or alfalfa root plugs in test tubes. As soon as the mycelium grew from the bits of tissue on to the plugs, the pieces were remored, to prevent contamination with slower-growing organisms. By the use of this method about 75 per cent of the cultures attempted rielded Ozonium.

Attempts were made to culture the mycelium making up the conidial mats, but in no instance was a pure culture obtained. Similarly, no pure cultures were obtained from the Ozonium strands when taken from diseased roots.

\section{THE FUNGUS}

No detailed account of the rarious stages of the fungus will be presented, as in the main the obserrations made by the writers are in accord with those of Shear (6), Duggar (1). Taubenhaus and Killough $(8)$, and others.

\section{STERILE MYCELIAL STAGE}

The type of sterile mycelium of the fungus Ozonium omniromum unirersally present on the healthy roots of the plants in adrance of the wilting zone is the strand hyphæ, composed of sereral or many bands of hyphr, the cells of which vary in shape and size. These strand hyphæ vary in color with age, but are usually buff or brownish. They branch off in a more or less regular fashion. but when spreading out over filter paper from an infected cotton root they may branch to produce a fan-shaped arrangement of strands. (PI. こ, fig. 1.)

These strands may be compared to some extent to the rhizomorphs of some of the Basidiomycetes. As has been pointed out before, the function of these strands appears to be in the nature of adrance mycelia, which spread through the soil and are responsible for the direct penetration and infection of the roots.

The acicular type of hyphæ is generally associated with the strands found on the roots. In culture this trpe has been found on cotton and alfalfa root plugs and sterilized soil, but not on any media containing agar.

The mycelial weft so prominent on the roots of diseased plants consists principally of large Rhizoctonialike hyphæ, together with some acicular hyphæ and a few strands. The large-celled hyphæ also form the major portion of the pseudosclerotia. although the outer surface may be corered by strands with acicular hyphæ.

The large-celled hyphæ break up and collapse very readily. Only the young growing tips of these hyphæ appear normal. The 
principal function of this type of mycelium appears to be to complete the destruction of the root tissues after penetration is accomplished and incidentally to serve as a food reserve for the adrancing strands beyond the wilting zone.

There are inter'mediate types of mycelium between those described, which vary in color, size, and shape, but they merge one into another so frequently that they do not stand out as sufficiently distinct to be described as different from those already mentioned. The greatest differences in the mycelium occur in the soil.

\section{CONIDIAL STAGE}

The conidial stage of Ozonium (Phymatotrichum omnivorum (Shear) Duggar) was observed at the United States field stations at San Antonio, Tex., and Sacaton. Ariz. The simplest form of the conidial stage may be called "abortive spore mats." These usually appear in cotton fields where root rot has been present in past seasons or is active, usually after every irrigation. In most instances these small abortive mats were found directly orer old dead cotton roots, covered with Ozonium strands. These strands could be traced from these old cotton roots directly through the soil to the surface, where mrcelium consisting of large barrelshaped cells of hyphæ could be observed arising from these strands. This mycelium is more or less branched in a fan-shaped or tufted manner. On the smaller ends and sides of these tufted hyphæ the spores were borne. These abortive spore mats were very small (1 to 2 centimeter's in diameter) and only a few layers of hyphæ in thickness.

The large well-organized mats vary greatly in size. Specimens were examined that ranged from 2 to 25 centimeters in diameter and from 0.5 to 4 centimeters in thickness. Usually the first indication of their development is the production of a loose mass of cobreblike mycelium, composed of large barrel-shaped cells. This mycelium usually collects a little beyond the outer edge of the wilting zone in a spot of root rot in an alfalfa field or on the periphery of a spot of cotton root rot, generally where it is well protected and shady.

This is followed by an accumulation of a creamy, fluffy mycelium, the extent and thickness of the mass being dependent on prevailing weather conditions. (Pl.6, fig. 1.) Where the mat continues to grow for more than one day each day's growth is clearly defined. (Pl. 6, fig. 2.) On the second day the first day's growth begins to turn dark. Spores are rapidly formed, so that by the end of the day the mass of mycelium has been replaced by spores, which in mass are of a buff color. Just as soon as the mats cease to derelop they become a buff-colored pulverulent mass of spores, similar to some of the puffballs.

The spore mats may appear at any time during the active growth of Ozonium, but only when conditions for their formation are farorable-cloudy weather with rain. together with a high soil moisture and high relative humidity. King (4) has giren an account of the numbers which may be produced in Arizona, their relative position about a spot of root rot and the conditions farorable for their development. 
All attempts to germinate the spores of the conidial stage failed, in spite of the fact that spores of all ages were used under many varied conditions, with a large number of soil and plant decoctions, stimuli, and other methods used in spore germination. In a few instances the spores obtained from newly formed spore mats placed in distilled water and held in an ice box became slightly swollen, and some semblance of a germ tube was produced; but otherwise no reaction of any sort occurred.

The conidial stage of Ozonium seems to be very similar to the Corticium stage of Rhizoctonia solani Kühn. In both instances the spore stage does not appear to be necessary in the life cycle of the fungus, as both organisms can maintain themselves from year to year by means of the sterile mycelium. The Corticium spores are very difficult to germinate; in fact, the only successful method developed has been the placing of spore-bearing material over an agar plate, and only a few of the mature spores which fall on the agar germinate. Although the germinating Corticium spores develop on agar to produce the sterile mycelium of Rhizoctonia, which in turn can cause infection, no one has yet succeeded in infecting susceptible plants with the spores. As in the case of Corticium vagum B. and C., it is doubtful whether the conidia of Phymatotrichum omnivomum will be found of any importance in the propagation, development, and spread of Ozonium.

\section{PERFECT STAGE}

Shear ( 7$)$ has recently described a perfect stage of this fungus which he has named Hydnum omnivorum, based on the connection between typical Ozonium hyphæ and the formation of a hymenium of the above-described Hydnum.

In this connection it might be stated that during the summer, and especially after every irrigation at Sacaton, Ariz., a number of small (2 centimeters) fan-shaped mats were found growing on the soil in well-shaded spots under cotton plants. Most of these mats were of an orange-yellow color. A number of these were dug out and found to arise from a rhizomorphic mycelium very similar to Ozonium strands on the old cotton roots invariably found under these mats. Specimens were sent to E. A. Burt, of the Missouri Botanical Gardens, who identified them as resupinate Hydnums.

Perhaps these specimens found so abundantly at Sacaton are the same as those described by Shear. Of course, final proof of this connection, as Shear states, must be obtained by germinating the spores of the Hydnum to produce the typical mycelium of Ozonium. It is interesting to note in this connection that the soils of the Southwest seem to be particularly adapted to the growth of many rhizomorphic fungi.

\section{INOCULATION EXPERIMENTS}

Of the many attempts to produce infection with Ozonium by those who have studied this disease, very few have been successful. Taubenhaus and Killough (8) reported the results of successful inoculations on 10 young plants of cotton. While no doubt the organism caused a wilting of the plants and could be recovered in culture, the plants were grown under very abnormal conditions. So far no one 
has reported successful inoculation with Ozonium on well-developed plants under greenhouse conditions. King (3), however, reports that he has infected cotton plants under field conditions.

During the summer of 1924 a number of inoculation experiments were attempted at Sacaton, Ariz. The fungus was grown in a sterilized mixture of sand and cotton roots in 2-quart Mason jars with modified caps. These jars were allowed to stand for several weeks until the soil was permeated with the strands of the fungus. In placing the inoculum in the field the jars were broken and the mass taken out intact, so that the mycelium which held the whole mass together was not disturbed.

All inoculations were made without wounding the roots on both cotton and alfalfa plants prior to irrigation. In most instances the inoculum was buried in a cotton row between two plants at a depth of 8 to 10 inches. As a supplementary aid, burlap sacks were spread over the point where the inoculum was buried in the soil, and these sacks were kept moist, so that conditions were ideal for the fungus to grow out and reach the plants.

In only one instance was the inoculum placed in direct contact with the roots of a cotton plant (the Acala variety), and this inoculation was the only successful one. The inoculation was made August 21, and complete wilting of the plant occurred September 15.

Under most of the burlap bags where the soil remained moist, abortive spore mats were found seven days after the inoculum was placed in the soil. The fruiting mycelium did not spread any farther after the first day and in a few days disappeared entirely. The spores produced in this manner when compared with spores from the large mats were identical in size, shape, and color. It seems strange that these abortive mats were produced from pure-culture material in the soil within a week, but that none of the plants near where these mats. were produced became infected.

To the writers it seems that the failure consistently to produce infection with pure cultures of Ozonium lies in the fact that we are dealing with a polymorphic fungus. As has been brought out before, the actual penetration of the plants is no doubt accomplished by the strand hyphæ, which are always found in advance of the wilting plants, while the mycelial weft so common on wilting plants serves to break up the host tissues in order to build up a food reserve to supply the active strand hyphæ in the advance zone. Under pureculture conditions the tendency of the fungus is to produce mycelium similar in nature to the hyphæ which make up the mycelial weft found on the roots of wilted plants rather than the strand hyphæ.

\section{DATA COLLECTED IN PREVIOUS YEARS}

A thorough digest was made of the root-rot data collected during the period from 1916 to 1924 in the rotation and tillage experiments at the field station near San Antonio, Tex., but no general correlations could be found, although some points of interest were brought out by this study. In all rotation and tillage experiments root rot was present to some degree every time a susceptible crop was grown. Although on the average the percentage of loss was lower than that in the continuous cotton plats, even on these plats the loss might vary from 2 to 96 per cent or more from one season to 
another, as it did in one plat studied. In other words, the behavior of Ozonium from one season to another is so erratic that no series of rotation or tillage experiments over a period of years can be undertaken with the idea of eliminating root rot from the soil. When a susceptible crop is grown during a season farorable for root rot following a nonsusceptible crop, the loss may be as high as on those plats grown continuously to a susceptible crop.

Further, the loss from root rot in duplicate plats may vary so widely that averages can not be justified. For example, two series of plats with a four-year rotation including cotton showed a difference over an eight-year period of 1.5 and 14.3 per cent, respectively, in loss from root rot. In other words, the percentage of root rot present from year to year may vary very greatly from plat to plat, and therefore comparative experiments can not be run satisfactorily.

There seems to be no correlation between the time of first appearance of root rot early in the season and the number of plants killed in the plats. Likewise, temperature does not seem to have any influence on the time of appearance or severity of root rot during the growing season.

In the vicinity of San Antonio, Tex., the most important factor involved in the seasonal loss from root rot appears to be precipitation. (Table 1.) A season ideal for root-rot activity would be one in which generous showers occurred frequently during the months from June to September.

TABLE 1.-Precipitation at the field station near San Antonio, Tex., during a five-year period for the three critical months of root-rot activity

\begin{tabular}{|c|c|c|c|c|c|}
\hline \multirow{2}{*}{ Month } & \multicolumn{5}{|c|}{ Rainfall (inches) } \\
\hline & 1919 & 1920 & 1921 & 1922 & 1923 \\
\hline $\begin{array}{l}\text { July } \\
\text { August } \\
\text { September }\end{array}$ & $\begin{array}{l}7.61 \\
2.22 \\
7.06\end{array}$ & $\begin{array}{r}1.66 \\
2.39 \\
.03\end{array}$ & $\begin{array}{r}1.40 \\
.02 \\
6.77\end{array}$ & $\begin{array}{l}0.12 \\
.02 \\
1.07\end{array}$ & $\begin{array}{l}2.16 \\
2.50 \\
3.02\end{array}$ \\
\hline $\begin{array}{l}\text { Total rainfall } \\
\text { A verage percentage of root rot for all plats... }\end{array}$ & $\begin{array}{l}16.8 \\
26.05\end{array}$ & $\begin{array}{l}4.08 \\
13.2\end{array}$ & $\begin{array}{l}8.19 \\
35.2\end{array}$ & $\begin{array}{r}1.21 \\
8.1\end{array}$ & $\begin{array}{l}7.68 \\
41.9\end{array}$ \\
\hline
\end{tabular}

A digest of the data collected in past years at the United States Field Station at Sacaton, Ariz., was also made. King (3 and 4) has issued two reports dealing with certain phases of this work. The most striking point observed at this station was the scattered distribution of root rot in the experimental plats. In many of these plats no root rot has ever been observed since the establishment of the station in 1907 , whereas at the station at San Antonio, Tex.", some loss from root rot has been recorded for every plat. It has been noted at the Sacaton station that the disease spreads from the point where it was first observed to adjacent plats, but the advance has been relatively slow. The spotted distribution of root rot throughout the irrigated valleys in Arizona is very characteristic. The same condition exists in southeastern California, as has already been pointed out. Owing to the fact that all crops are grown under irrigation, the percentage of loss from root rot from year to year is much more uniform than in Texas. 
OBSERVATIONS DURING THE SUMMER OF 1924

Prior to June 30 a few root-rot centers were present in border C 2-24 at the United States Field Station, Sacaton. Ariz. This border, planted to Pima cotton, was included in a spacing experiment. The first three rows consisted of plants widely spaced (12 to 15 inches). whereas the other four rows were closely planted (about 12 to 15 plants per foot).

By taking a count of the number and location of the dead plants on alternate days an opportunity of watching the spread of root rot under two different conditions in one plat was afforded. During the growing season the border was irrigated on April 15, May 23, June 24, July 18, August 12, September 2, and September 26. From

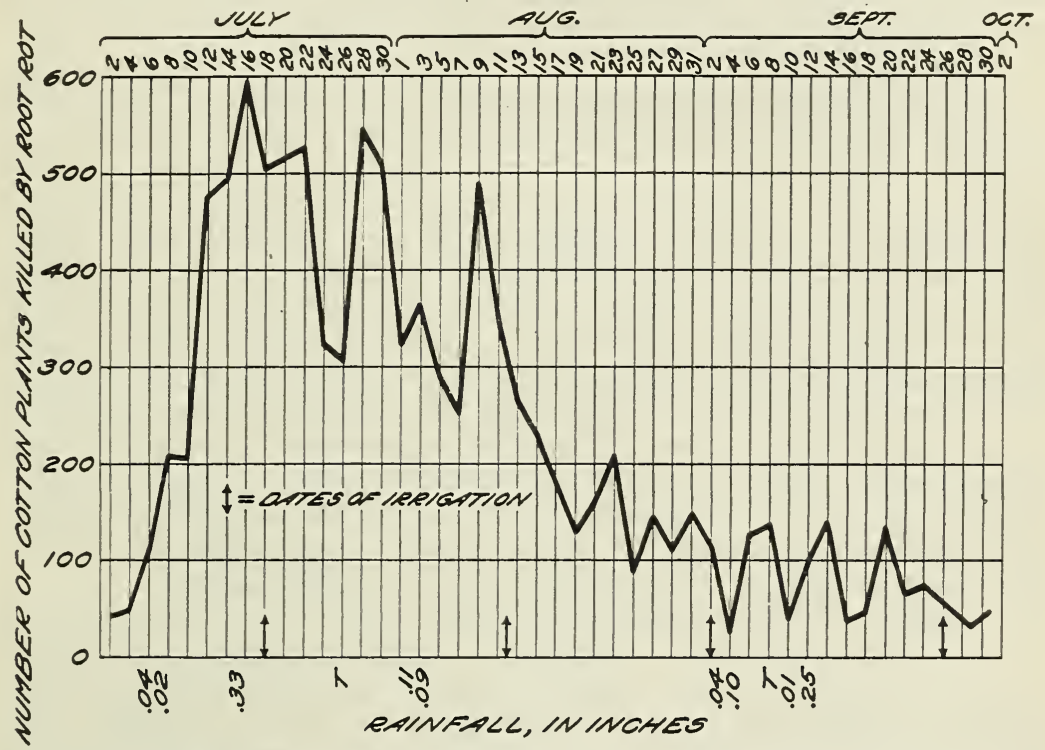

FIG. 2.-Diagram showing the number of cotton plants killed by root rot in border C-2-24 at Sacaton, Ariz., each alternate day from July 1 to October 1,1924

June 30 to October 1, 0.99 inch of rain fell in the form of scattered showers. The heaviest shower consisted of 0.33 inch. The rainfall for the summer months being below normal and almost negligible as far as the quantity is concernerl. it is assumed that irrigation alone influenced the progress of root rot.

Figure 2 shows the death rate of the plants in the border. If this diagram is studied it will be found that, beginning with the second week in July, the mortality of the plants was extremely high and remained so with the exception of two pronounced fluctuations until the second week in August, when the death rate dropped very rapidly and continued to do so more or less until the end of the season. In other words, almost 75 per cent of the plants which died in this border did so during the interval between July 8 and August 15 . 
When the number of widely spaced plants which died from root rot was compared with those closely planted it was found that for the area of the ground which was occupied by each the percentage of plants killed was the same. In other words, although many more plants were killed by root rot in the closely planted rows, the advance of Ozonium in the soil was just as rapid in the widely spaced rows of cotton.

The decided fluctuations in the death rate of the plants can be explained by the fact that after every irrigation a smaller additional number of plants showed symptoms of the disease. Howerer, the effect was only of a temporary nature, as can be seen by the larger mortality a few days later, so that, although the application of water retarded the diseased plants from wilting for a short period, the application of irrigation water really increased the death rate of the plants. No doubt a period of wet, cloudy weather would have the same effect.

The data obtained on alternate days on the number of dead plants. and their location were plotted to determine whether the spread of Ozonium in the soil could be determined from day to day, but the behavior of the disease was so erratic that no definite correlation could be made. Although definite centers of infection were present when the count was begun, these centers did not spread in a regular fashion. Some centers, after a number of plants were killed, ceased to grow larger; others ceased for a time and later enlarged again. Occasionally one plant after another down the rows for a considerable distance was progressively killed off. At other times the fungus would skip for several feet, kill a few plants, and then spread to an adjacent row. Then, as time went on, the plants not killed at first would begin to die off rapidly. At the end of the season, however, the irregular spots united so that the last plants killed by root rot were more or less on the periphery of the circular areas.

A number of other borders were charted in the same manner as the one just mentioned. Table 2 is representative of what was found. In these borders root rot appeared somewhat later than in border C 2-24, but an idea of the progress of root rot is given. This series of borders includes an experiment that is being conducted on the influence of manures in the inhibition of root rot.

TABLE 2.-Bimonthly count of the number of cotton plants killed by Ozonium root rot in a series of borders manured and untreated at sacaton, Ariz., during the summer of 1924

[Each border had approximately 2,600 plants]

\begin{tabular}{|c|c|c|c|c|c|c|c|c|}
\hline \multirow{2}{*}{ Borders } & \multirow{2}{*}{ Treatment } & \multicolumn{7}{|c|}{ Number of plants dead } \\
\hline & & July 31 & Aug. 15 & Sept. 2 & Sept. 17 & Oct. 2 & Oct. 31 & Total \\
\hline 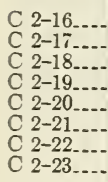 & 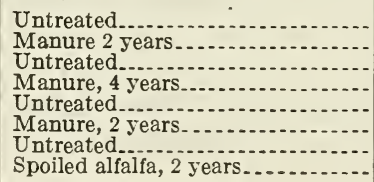 & $\begin{array}{r}21 \\
4 \\
22 \\
4 \\
18 \\
3 \\
38 \\
5\end{array}$ & $\begin{array}{r}42 \\
22 \\
102 \\
4 \\
13 \\
17 \\
76 \\
17\end{array}$ & $\begin{array}{r}116 \\
31 \\
136 \\
14 \\
58 \\
101 \\
186 \\
54\end{array}$ & $\begin{array}{r}129 \\
28 \\
141 \\
15 \\
93 \\
114 \\
163 \\
78\end{array}$ & $\begin{array}{r}106 \\
28 \\
113 \\
4 \\
67 \\
97 \\
96 \\
51\end{array}$ & $\begin{array}{r}33 \\
20 \\
27 \\
1 \\
17 \\
25 \\
47 \\
13\end{array}$ & $\begin{array}{l}447 \\
133 \\
541 \\
42 \\
266 \\
357 \\
606 \\
218\end{array}$ \\
\hline
\end{tabular}




\section{SUMIARY OF PART I}

Trpical strands of @zonium omnivorum hare been found on the roots of sereral plants native to the Southwest, both on roots of sprouts in recently cleared land planted to cotton under root-rot spots and on roots of these plants growing in their native habitat.

Ozonium omnivorum appears to be indigenous in the soils of certain regions of the southwest section of the United States and yearly canses large economic losses, principally to cotton, alfalfa, and fruit trees in Texas and in certain irrigated valleys of New Mexico, Arizona, and southeastern California.

A study of exhumed root systems of susceptible plants at various stages of infection gave no evidence that the mycelium of Ozonium spread from plant to plant by underground contact of diseased with healthy roots, but indicated that the fungus usually progresses radially from a center through the soil. irrespective of the root systems, and attacks the plants in the line of the advancing mycelium. The plants are generally attacked on the taproot within the first foot of soil, and the laterals usually rot from the point of attachment with the taproot.

The actual agent in the penetration of the roots is the strand hyphæ, which are found approximately 38 to 75 centimeters in adrance of the wilting zone of plants. The hyphæ composing the mycelial weft found on the wilting plants appear to complete the breaking down of the roots and act as a reserve food supply for the adrancing strand hyphæ. This mycelial weft disintegrates and disappears as soon as the roots are rotted.

At the close of the growing season the only active mycelium is slightly in advance of the periphery of the root-rot spots, and it is at this point that new centers of infection usually occur the following year. From the evidence at hand it does not appear necessary that the roots on which these strand hyphæ are present remain alive during the winter. From these new centers of infection the organism can again spread out radially.

To judge from the scattered distribution of root rot in fields in the irrigated districts of Arizona and southeastern California and from the difficulty of infecting plants with pure cultures, the organism is not commonly spread by any aboveground agency, including the spores of the conidial stage.

The difficulty encountered in attempting to infect susceptible plants with pure cultures of Ozonium may be due to the polymorphic nature of the fungus, which tends to produce in culture the large-celled type of mycelium rather than the strand hyphæ found in the advance zone under field conditions. Of the inoculations made at Sacaton, Ariz., during the summer of 1924, the only successful one was by direct contact.

Because of the extremely erratic behavior of the fungus in the field, no correlation could be made with certainty with any environmental factor or factors. The only factor which seemed to have any influence on the spread and severity of root rot was the amount of precipitation occurring during July, August, and September, and this appeared to be of only slight influence in the irrigated region. Until the relation of the environmental factors can be determined under controlled conditions, the data already collected under field conditions can not be interpreted. 


\section{PART II.-THE PATHOLOGICAL ANATOMY OF OZONIUM ROOT ROT}

By George L. Peltier and Raibltri $\pi$. Samson

\section{INTRODUCTION}

In order to determine the type of hyphæ involved in the penetration of the roots of susceptible plants, the modes of entrance, and the subsequent development of the disease, material representing rarious stages of root rot on alfalfa and cotton plants was obtained at the United States Field Station at Sacaton, Ariz. A few roots of the common mesquite (Prosopis glandulosa Torr.) and the granjeno (Momisia pallida (Torr.) Planch.) with Ozonium strands present were also collected.

This study does not presume to be complete in many respects, for the quantity of material studied was not sufficient nor was it representative of all conditions found in the field. Further, time did not permit an elaborate examination of all the material at hand, but enough was studied to cover the whole field in a preliminary way.

To aroid repetition, the writers assume that the readers are familiar with the macroscopic symptoms and derelopment of the root rot and the various mycelial forms of this fungus, as heretofore described.

\section{MATERIAL AND METHODS OF STUDY}

The material representing the cotton and alfalfa roots was obtained at the time root excavations were made at Sacaton, Ariz., during the summer of 1924 (p. 5).

One criticism of the material used in this study can be offered. especially where the later stages of the disease are involved-the presence of secondary invaders in the plant tissues. It is realized that material from pure-culture inoculations would aroid any misinterpretation. As has been pointed out, rery few successful inoculations have been made with Ozonium on susceptible plants, so that material gathered in the field had to be employed. Pure cultures of Ozonium, however, were obtained from the material which was collected for this study.

The roots of the plants representing the various stages of root rot were placed in chromo-acetic acid, Fleming's solution (medium and weak), and Gilson's fixatives and finally embedded in paraffin in the usual manner.

Two differential stains were employed. those of Durand (2) and Vaughan (9). The latter, a modification of Pianese's stain, produced the best results and was used for the most part in coloring the sections.

\section{THE STRAND HYPHAE}

Contrary to general opinion, the strand hyphæ are composed of a large central hypha (pl. $7, \mathrm{~A}$ ), which is generally filled with a mass of granular material which colors a deep red with Pianese's stain. Around this central cylinder are small, rather irregular-shaped, thick-walled hyphæ. From three to six bands of these hyphæ are 
present, depending on the diameter of the strand. The hyphæ stain red, but owing to the fact that the cell contents are not as dense as in the central hypha, they do not stand out so sharply.

When branching of the strands occurs the central hypha only is found to branch, whereas the outer band of smaller hyphæ do not branch, but run along continuously. Just what the function of this large central hypha is was not determined. It appears to be continuous and probably serves as a food reserve for the mycelium which invades the root tissues of the plant.

The diameter of the strands varies greatly. Those found on the mesquite root (pl. 7, A) are at least twice the diameter of the strands found on cotton and alfalfa roots (pl. 7, B, and pl. 8, A) during the summer. Likewise they are much more compact and consist of more layers of smaller hyphæ. Strands observed on cotton roots which wintered orer were found to be more like those studied on the mesquite roots both in size and compactness. The strands found during the summer months are of a looser nature and not so well organized. Using various types of polarized light, no differences could be detected between the nature of the component parts of the strands or between the strands found on the various hosts.

The acicular hyphæ (pl. $7, \mathrm{~A}$ and B) stain rery lightly or not at all. They arise from more or less triangular cells in the outer band of hyphæ.

\section{MODES OF ENTRANCE}

Three arenues of entrance into the root tissues of cotton plants have been observed-through lenticels (pl. 9, B), through wounds of various kinds, and by the direct penetration of the hyphr between the cork cells. (Pl. 8, A, B, and C.) Infection of the roots through the lenticels is of common occurrence. Direct penetration of the hyphæ between the cork cells is rather uncommon.

On alfalfa roots, in addition to the three portals mentioned above, a fourth one has been noted, which ranks next to the lenticels in the frequency with which it has been observed. Entrance in this instance is through the small fibrous rootlets attached to the main taproot. (Pl. 10, A and B.) Penetration usually takes place in the angle at the junction of a rootlet and the taproot, generally through a break in the corky layer. Direct penetration of the alfalfa roots appears to be effected more easily and is more common than with cotton. This is due to the fact that the layer of cork cells on cotton roots is thicker and more compact than the cork cells on the alfalfa roots.

\section{MECHANICS OF ENTRANCE}

The hyphæ involved in the actual penetration of the roots arise from the central hypha of the strands. The central hypha branches profusely on the side of the strand in contact with the roots. Soon an accumulation of mycelium (pl. 9, A) is formed, composed of rather large, irregular-shaped, thick-walled, many-nucleated hyphæ, at first with only an occasional cross wall. The protoplasm is extremely dense and granular and stains a deep red with Pianese's stain. The contents of these hyphre appear similar in all respects 
to those found in the central hypha of the strands. The outer band of hyphæ composing the strand forms a sort of protective layer over the weft of mycelium which apparently develops very rapidly. (Pl. 7, C.)

After the weft has reached a sufficient size, penetration is accomplished by the formation of a wedge of hyphæ which adrances between the cells of the lenticels or cork. (Pl. 8, B and C, and pl. 9, B.) The wedge pushes its way down between these cells in a mechanical fashion. The cells themselves are not attacked, but remain intact and are finally engulfed in the fungous mass. Later they collapse, and the old cell walls stained green by the Pianese differential stain can be observed scattered about in the red-stained mycelial mass.

That the host plants react to this fungous invasion can be seen in Plate 8, B, where the cork cambium (cell walls stained green) is attempting to wall off the lenticel. Thus, until the hyphæ reach the cork cambium, the process of penetration is mechanical and in some respects is similar to the action of ectotrophic mycorrhizas.

\section{DEVELOPMENT OF THE HYPHÆ IN THE TISSUES}

As soon as the fungous wedge reaches the cork cambium, the hyphæ become differentiated from that composing the wedge. (Pl. S.D. and pl. 11, A.) The hyphæ become smaller and more irregular in shape, and the cell contents are less dense and more granular. The nuclei are less prominent, and more cross walls occur. Branching of the hyphæ also occurs more frequently. From this point of entrance to the cork cambium the hyphæ invade it in all directions and likewise advance into the parenchyma of the cortex. (Pl. 8, D, and pl. 11, A.) The advance into the cork cambium is very rapid, much more so than into the parenchyma. The hyphæ are found at first in between the cells, but later are found in the cells also. 'The cells of the cork cambium and cortex are rapidly broken down, and some collapse. The bast fibers and sieve tubes remain intact and can be observed among the broken-down cells. (Pl. 9, C.)

When enough of the parenchyma cells are broken down, a sunken area or depression is formed. (Pl. 9, C.) While the hyphæ have been advancing and breaking down the cells to form a depression the mycelium has been piling up to form a rather thick compact mass of hyphæ, similar to the hyphæ which were responsible for the penetration between the cork cells.

By the time the advancing hyphæ reach the cambium the depression is rather large. When this stage is reached the depression does not increase in diameter, although the hyphæ advance rapidly in all directions from the depression. The cork cells remain intact on each side of the depression even though the cells beneath are badly diseased. (Pl. 11, A.)

The hyphæ rapidly destroy the cambium in all directions from the points of attack. The stele is also invaded, so that by the time the plant is dead fungous mycelium can be found throughout the stele in the invaded area. This, in short, is a description of the penetration and development of the fungus at only one point. When it is realized that the strand hyphæ envelop the taproots of an alfalfa or cotton plant and that many depressions are formed, it is not to 


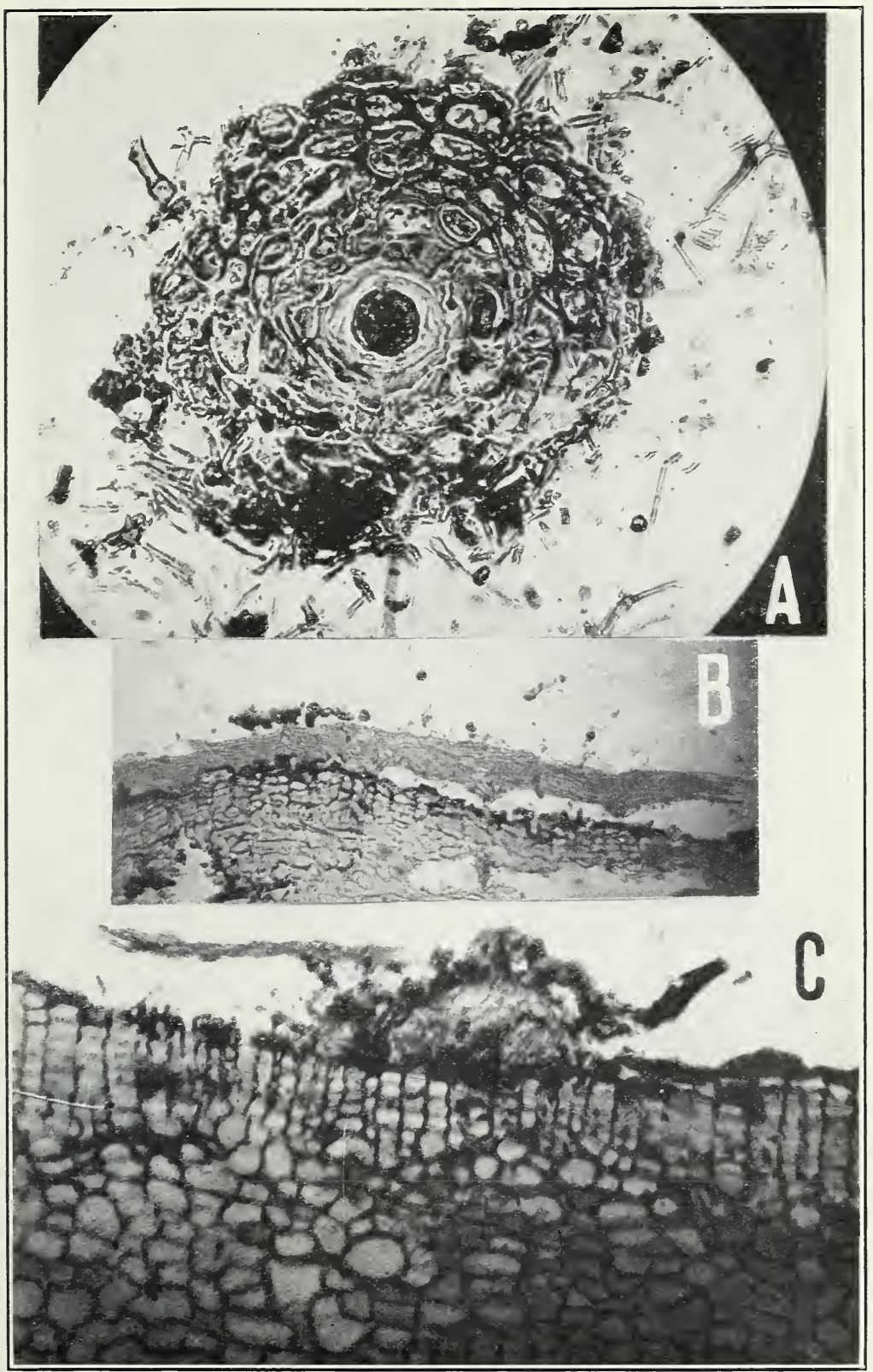

\section{STUDIES OF OZONIUM STRAND HYPHEE}

$A$, Cross section of an Ozonium strand from a mesquite root, showing the large central hrpha, whose contents are granular, and the outer bands of hyphæ. The scattered fragments on the outer edge of the strand are the acicular hyphæ $(\times 368)$. B, Longitudinal section of an alfalfa root, showing an Ozonium strand in contact with the root surface. Note tho hyaline, acicular hyphæ arising from the strand $(\times 75)$. $C$, Longitudinal section of an alfalfa root, showing an Ozonium strand beginning to form an accumulation of hyphæ pre paratory to the penetration of the fungus between the cork calls $(\times 150)$ 


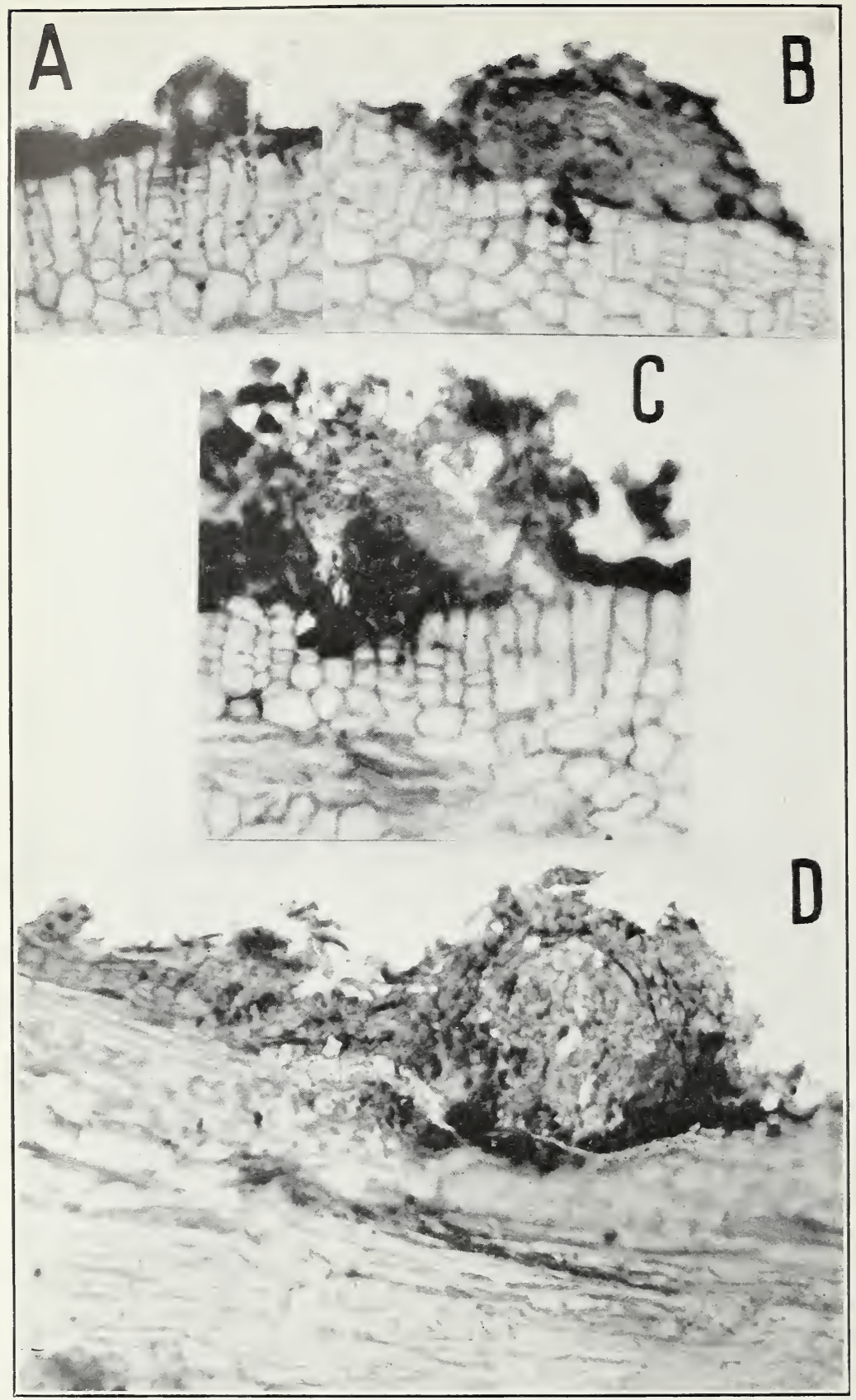

\section{Longitudinal SECTIONS OF ALFALFA ROOTS}

$A$, Single Ozonium strand, with the central hyphæ missing $(\times 162)$. B, Formation of the mycelial, weft and the entrance of the hyphal wedge between the first two rows of cork cells $(\times 156) . \quad C, A$ later stage than $B$, showing a well-developed wedge $(\times 175) . D$, Invading hyphre between the cork cells and invading the cork cambium and some of the parenchyma cells. Note the difference between the hyphæ making up the wedge and those breaking down the cortex. The cork cambium is beginning to collapse, the first indication of a depression being visible. Entrance in this instance was effected through a lenticel. The engulfed lenticel cells can be seen in the fungous accumulation $(\times 109)$ 


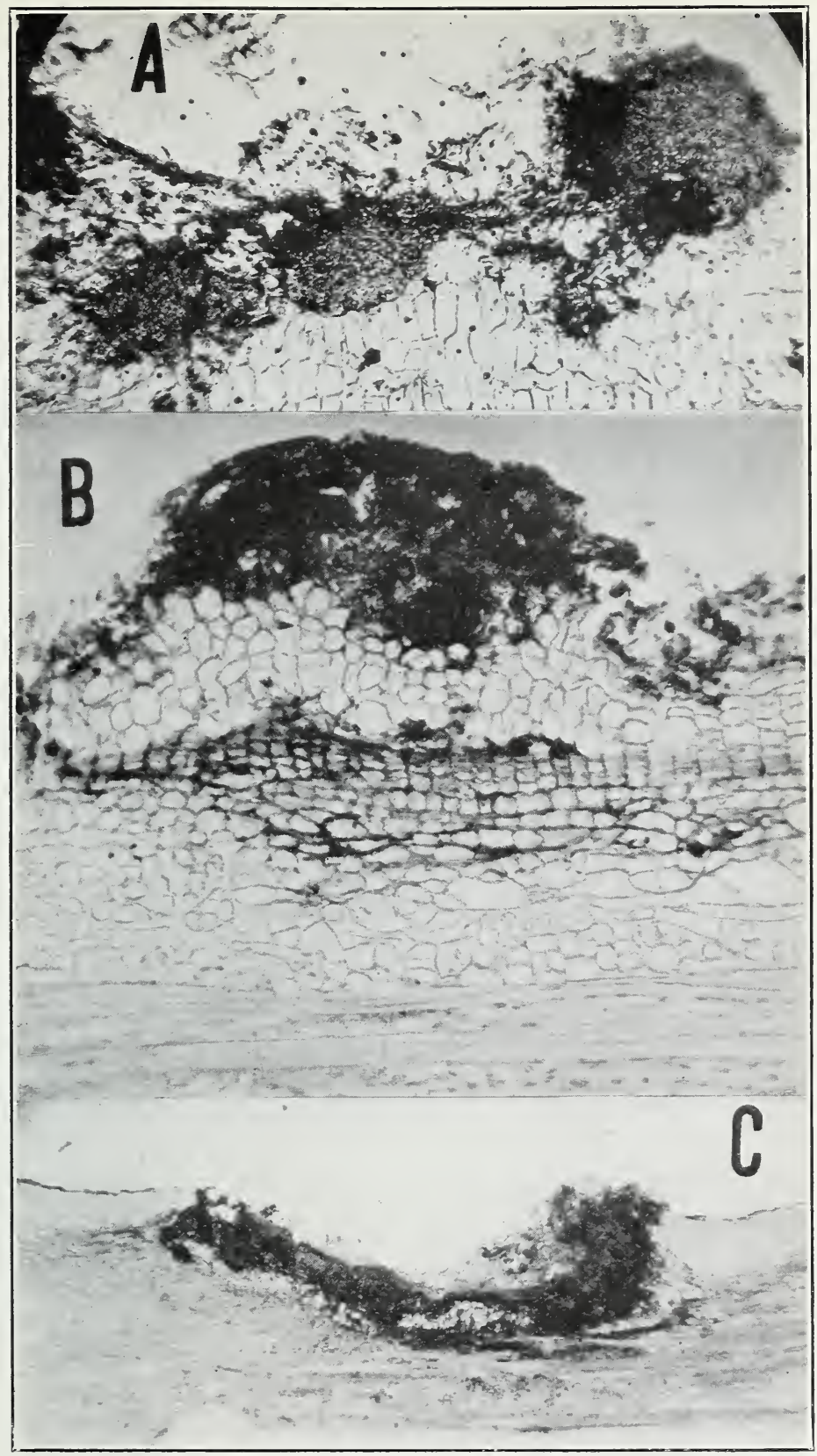

LONGITUDINAL SECTIONS OF COTTON ROOTS

$A$, Longitudinal section of the cork cells of a cotton root. showing the branching of Ozcnium strands to form accumulations or wefts of the invading hyphæ $(X 75)$. $B$, Longitudinal section through a lenticel of a cotton root, showing the mycelial mass and the penetration of the hyphal wedge between the cells. Below can be seen the formation of a wall of cork cambium apparently trying to wall off the lenticel $(\times i 3), C$, Longitudinal section of a cotton root, showing a trpical depression in which an accumulation of the hyphæ appears $(\times 25)$ 


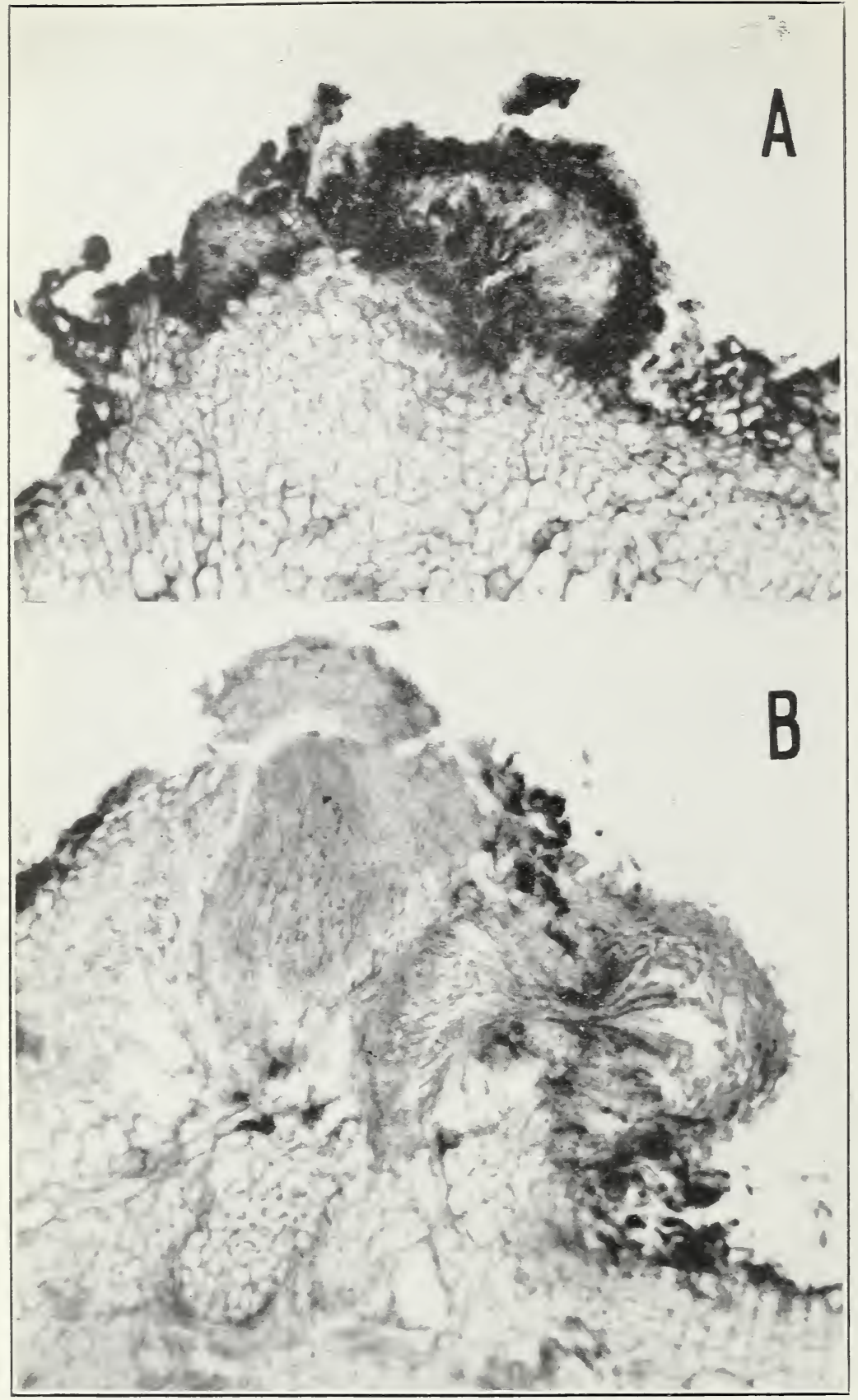

LONGITUDINAL SECTIONS OF FIBROUS ROOTLETS AT THE JUNCTION WITH THE TAPROOT OF ALFALFA

$A, A$ well-dereloped weft of hyphæ and the hrphal wedge invading the cork cells $(X 116)$. $B, A$ somewhat later stage, showing how the hyphæ spread out after the wedge pushes through the cork cells. Note also how the hyphæ become differentiated as soon as this occurs $(\times 119)$ 


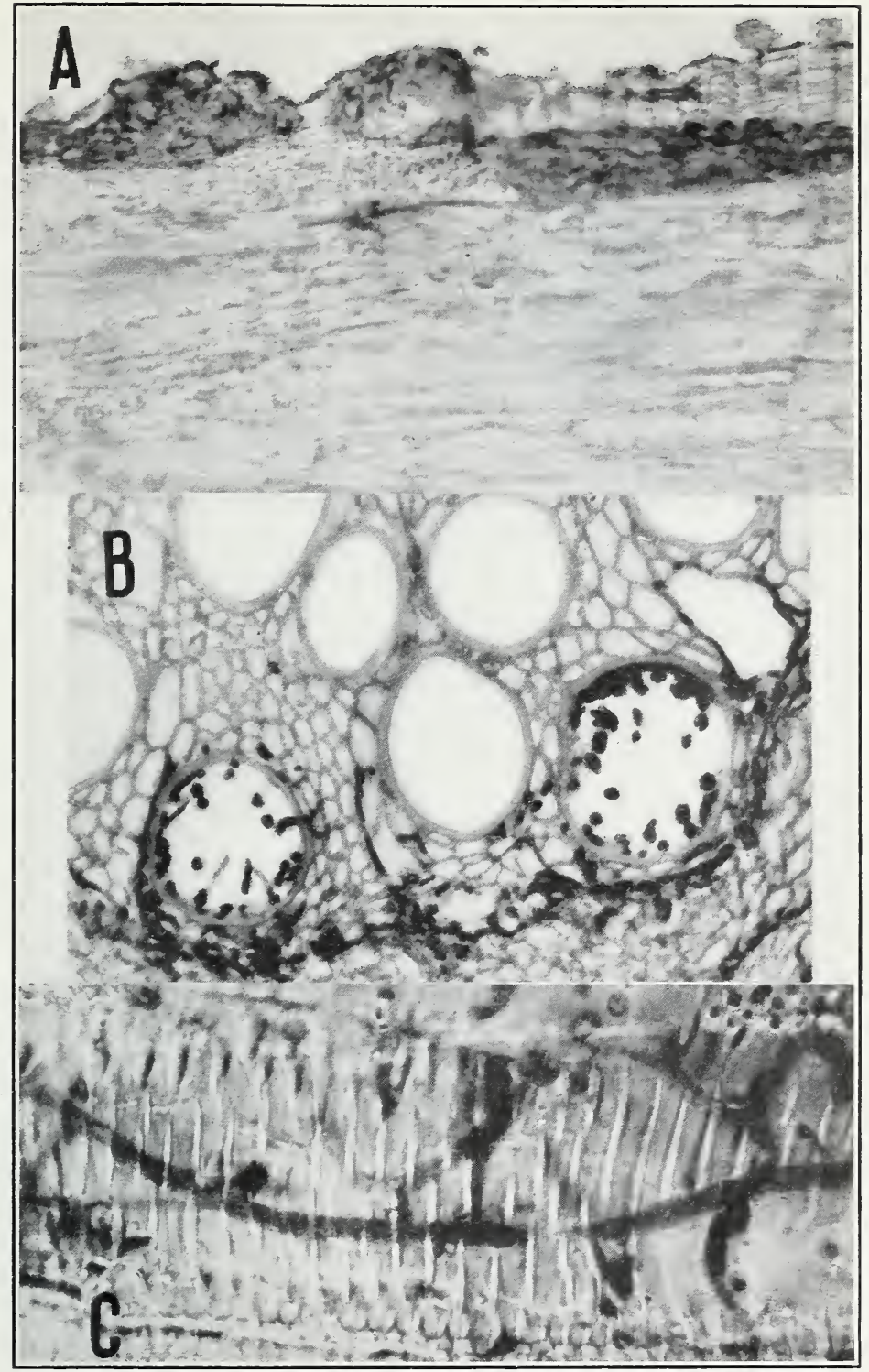

\section{RESULTS OF HYPHEE INVASION}

$A$, Longitudinal section of an alfalfa root, showing two points of entrance near together. The cork cambium can be seen almost totally invaded by the hyphæ at the right, while the cork cells are perfectly healthy. Note, just above, the cross sections of two strands. Practically all of the parenchyma cells areinvaded by the fungous mycelium $(\times 166)$. $B$, Cross section of a lateral root of cotton 45 centimeters beyond the diseased portions, showing the abundance of hyphæ in the outer vessels of the xylem. No strands were found on the surface of these roots, nor were there any indications of fungous invasion in any part of this section except in the vessels shown $(\times 220)$. C, A spiral vessel in the region of the rotten portion of an alfalfa root. showing the fungous hyphæ within the vessel. These hyphæ can apnarently go down these ressels for some distance. See $B$. $(\times 630)$ 

be wondered at that under optimum conditions for the development of the disease a plant is killed within one week after the strands are first found on the roots.

As has already been pointed out, the point of attack centers on the taproot of both cotton and alfalfa plants within the first foot of soil. Sections were made of both the taproots and lateral roots out away from the diseased areas and near the ends of both lateral roots and taproots of plants just wilting. These sections do not show the presence of the fungous strands on the surface of the roots or of the invading hyphæ within the root. From the ends of the healthy taproots and lateral roots sections have been taken at regular interrals to the union of the taproots with the lateral roots of cotton. On plants just wilting, sections made from lateral roots 30 to 50 centimeters away from their union with the taproot show no strands on the surface, although the outer xylem vessels were found to be filled with the fungous hyphæ. (Pl. 11, B and C.) Entrance to these vessels occurred at the main point of attack on the taproot. Similarly, sections made of alfalfa beyond the diseased portions for 50 centimeters showed the presence of fungous hyphæ within the outer xylem ressels, while no strands were present on the roots. The tissues of these sections were intact and healthy appearing in all respects, so that it is clear that the Ozonium strands do not attack the roots below the first foot of soil, but they center their attack on the taproot above this point.

Sections were made in the discolored regions of the stem abore the junction of the root and the stem, but no fungous mycelium was found within the tissues, so that the discoloring of the tissues must be due to causes other than the presence of an invading fungus.

\section{DISCUSSION}

The derelopment of the strand hyphæ when they come in contact with the root tissues should be studied more at length. to determine how the central hypha of the strands branches to build up the mycelial accumulations preparatory to the formation of the wedge that is pushed down through the cells of the lenticel or the cork. So far as the writers are aware, this type of entrance has not as yet been described.

The most common portal for Ozonium hyphæ entering the root tissues of alfalfa and cotton is the lenticel. A study of lenticels, their number, size, and vertical distribution on the roots, the age of the plants when they first appear, and the effects of irrigation on their derelopment, should determine the importance and frequency of lenticel infection and solve some of the points which are not as ret clearly defined. Until this is done the complete development of the disease will remain obscure.

Whether infection occurs through the lenticels or cork cells, the method of entrance is the same and appears to be mechanical, namely, the formation of a hyphal wedge which pushes its way down between the cells until the cork cambium is reached, when there appears to be a rapid differentiation of the hyphæ. These hyphæ advance in all directions, and they may be found intercellular and intracellular. The accumulation of the hyphæ in the cortex cells is remarkable. In 
some instances mats of mycelium have been observed in the cortex filling 10 to 12 rows of cortex cells, where the latter have collapsed.

The fact that a cotton or an alfalfa plant can be killed in one week shows that the fungus develops within the tissues of the roots very rapidly. Further, the large mass of mycelium present on the roots of the plants after they are wilted indicates that the fungus is a voracious feeder. This mycelium apparently serres as a food reserve for the strand hyphæ, which are found well in advance of the wilting plants, as has already been pointed out. The fact that this type of mycelium serves as a reserve is further substantiated when one notes the rapidity with which the fruiting or conidial mats are formed (p. 13).

It would be interesting to trace the connection between the mycelium found on the wilting plants and the strand hyphæ found well in advance to these plants, to determine just how the strand hyphæ are formed and how the central hypha arises. At any rate it is clearly evident that we are dealing with a polymorphic fungus, the complete development of which can not be determined until the origin and function of the different types of hyphæ are studied at length.

\section{SUMMARY OF PART II}

Material representing various stages of root rot caused by $O z o$ nium omnivorum on alfalfa and cotton roots, together with Ozonium strands on mesquite roots, was collected at Sacaton, Ariz., and San Antonio, Tex., during the summer of 1924 in connection with an investigation of root rot. These materials were fixed in three common fixatives, embedded in paraffin, stained with Pianese's differential stain, and a study made of the pathological anatomy of the disease.

The strand hyphæ are composed of a large central hypha around which are bands of smaller hyphæ. The acicular hyphæ so conspicuous on the strands arise from cells of triangular shape in the outer band of smaller hyphæ.

The central hypha of the strands branches profusely to form a dense weft of large, irregular-shaped, thin-walled, many-nucleated hyphæ, at first showing only an occasional cross wall at points on the roots.

Entrance to cotton roots is effected by the hyphæ of these refts through the lenticels, through wounds of various kinds. and by direct penetration of the fungus between the cork cells. In addition, a fourth portal was observed in alfalfa roots--the entrance through the small fibrous rootlets where they are attached to the taproot.

Entrance is effected by the formation of a hyphal wedge, which pushes its way down between the cork and lenticel cells until the cork cambium is reached.

The hyphæ on reaching the cork cambium become narrower, with longer cells, containing a protoplasm less dense but more granular than the hyphæ responsible for the actual penetration.

These invading hyphæ advance in all directions through the cork cambium and into the cortex. The hyphæ are present in and between the cells, and in a short time enough of the parenchyma cells are broken down to form a depression in the bark. 
The cambium is rapidly broken down, and the stele is invaded through the avenues of least resistance.

Many such depressions are found on the roots, so that it is evident why the death of an alfalfa or cotton plant under optimum conditions for the disease is effected within a week.

Finally the stele elements are broken down and disorganized, and upon the invaded tissues the mycelium, which serves as a reserve for the strand hyphæ, grows profusely.

The polymorphic nature of Ozonium, together with its unusual method of entrance and its subsequent behavior within the tissues, makes it an extremely interesting subject for extended investigations. 



\section{LITERATURE CITED}

(1) Duggar, B. M.

1916. the texas rootrot fungus axd its coxidial stage. Ann. Mo. Bot. Gard., vol. 3, p. 11-23, illus.

(2) Durand, E. J.

1911. THE DifFerential StaiNing of IYTercellllar MYCelium. Phytopathology, vol. 1, p. 129-130.

(3) KING, C. J.

1923. сотton RоOtrot in ARIzoNa. Jour. Agr. Research, rol. 23, p. 525527.

(4) 1924. habits of the cotтox воотвот FUigus. Jour. Agr. Research, vol. 26 , p. $405-418$, illus.

(5) SCOFIELd, C. S.

1919. соттол воотвот spots. Jour. Agr. Research, rol. 18, p. 305-310, illus.

(6) SHear, C. L.

1907. NEW SPECIES of FUNGI. Bul. Torrey Bot. Club, vol. 34, p. 305-317.

(7) 1925. THE LIFE HISTORY OF THE TEXAS ROOT-ROT FUNGUS, OZONIUM OMNIVORUM shear. Jour. Agr. Research, vol. 30, p. 475-477, illus

(8) Taubenhaus, J. J., and Killough, D. T.

1923. texas rootrot of COtTon aNd methods of its Control. Tex. Agr Exp. Sta. Bul. 307, 98 p., illus.

(9) Vaughan, R. E.

1914. A METHOD FOR THE DIFFERENTIAL STAINING OF FUNGOUS AND HOST CELLS. Ann. Mo. Bot. Gard., vol. 1, p. 241-242. 


\section{ORGANIZATION OF THE \\ UNITED STATES DEPARTIENT OF AGRICLITURL}

August 9, 1926

Secretary of Agriculture

IV. M. JARDINE.

Assistant Secretary R. IV. DUNLAP.

Director of Scientific Work

Director of Regulatory Work

Walter G. Campbei.l.

Director of Extension Work C. W. Warburton.

Director of Information

Nelson Antrim Crawford.

Director of Personnel and Business Admin-

istration

Solicitor

Weather Bureau

Bureau of Agricultural Economics

Bureau of Animal Industry

Bureau of Plant Industry

Forest Service.

Bureau of Chemistry

Bureau of soils.

Bureau of Entomology

Bureau of Biological Survey

Bureau of Public Roads.

Bureau of Home Economics

Bureau of Dairying

Fixed Nitrogen Research Laboratory

Office of Experiment Stations.

Office of Cooperative Extension Work

Library

Federal Horticultural Board

Insecticide and Fungicide Board

Packers and stockyards Administration Grain Futures Administration
W. W. STOCKBERGER.

R. W. Williams.

Charles F. Marvin, Chief.

Lloyd S. TenNy, Acting Chief.

JOHN R. MOHLER, Chief.

William A. Taylor, Chief.

W. B. Greeley, Chief.

C. A. Browne, Chief.

Milton Whitney, Chief.

L. O. Howard, Chief.

E. W. Nelson, Chief.

Thomas H. MacDonald, Chief. Louise Stanley, Chief.

C. W. Larson, Chief.

F. G. Cottrent, Director.

E. IV. Allen, Chief.

C. B. Smith, Chief.

Claribel R. Barnett, Librarian.

C. L. Marlatt, Chairman.

J. K. Haywood, Chairman.

John T. CaINe, in Charge.

J. IV. T. Duves, in Charge.

This bulletin is a contribution from

Bureau of Plant Industry

Office of Cotton, Rubber, and Other. Tropical Plants
William A. Taylor, Chief.

O. F. Cоoк, Senior Botanist, in Charge.

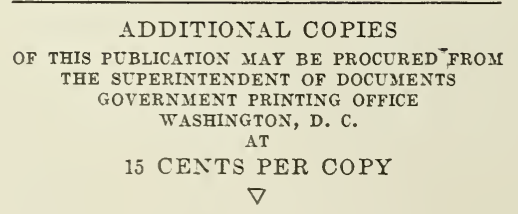


$\int-1, y=0$

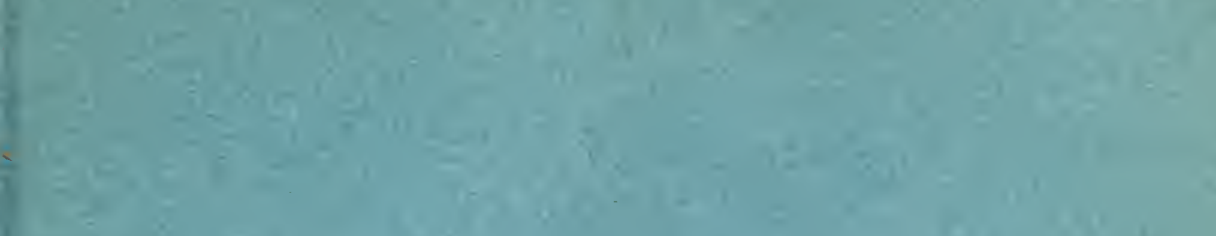

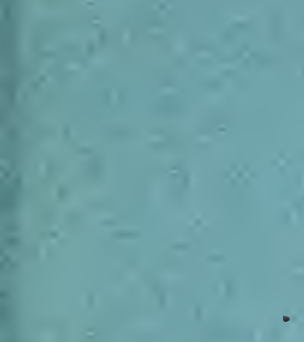

8

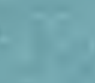

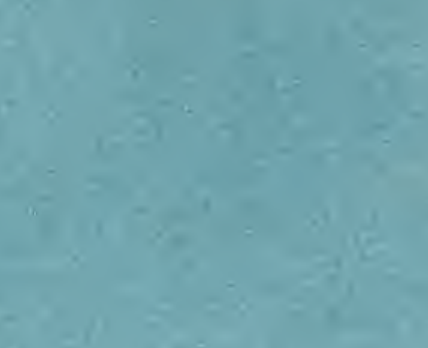

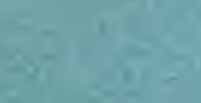

$\frac{1}{2}$

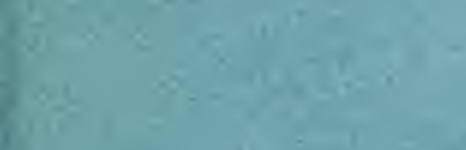

(1)

$x^{2}+1=2$

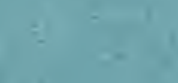

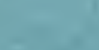

(2)

$y=$

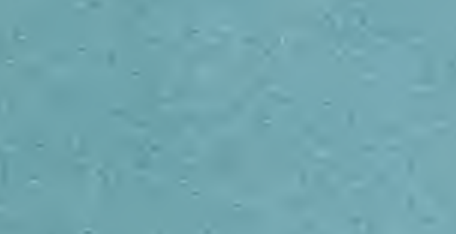

$-8^{3}-4+4 \frac{5}{x}=$

$f^{\prime}=$

1

T 
